\title{
CONTRIBUIÇÃO AO ESTUDO DE LASIODERA GRAY E PHILYRA LAPORTE, GEN. REV. (COLEOPTERA, CLERIDAE)
}

\author{
Francisco Racca Filho ${ }^{1}$ \\ Adriano Lucio Peracchi ${ }^{1,2}$
}

\begin{abstract}
Contribution to the study of Lasiodera Gray e Philyra Laporte, Gen.rev. (Coleoptera, Cleridae). This paper includes a revision of the species considered up to now in the genus Lasiodera Gray, 1832 with a detailed study of external morphology as well as males external genitalia which made to propose the separation into two genera, Lasiodera Gray, 1832 and Philyra Laporte, 1836, beeing the second one revalidated, which is now constituted by the following species: Philyra basalis (Racca Filho \& Santos, 1988) comb.n., P. helopioides Laporte, 1836 comb.n., P. jucunda (Schenkling, 1900) comb.n., P. quadrivittata (Peracchi, 1960) comb.n., P. stenochioides (Chevrolat, 1874) comb.n. and P. viridis (Pic, 1936) comb.n.. The male genital structures, showing specific differences, are illustrated and discussed. Lasiodera malleri (Pic, 1933) is considered a synonym of L. ruficollis (Gorham, 1877). Lasiodera ornata (Klug, 1842) and L. voluptuosa (Thomson, 1860) had not their external genitalia examinated because they are not represented in the collections studied. To identify the species of the genera, systematic keys are also presented.

KEY WORDS. Coleoptera, Cleridae, Lasiodera, Philyra
\end{abstract}

Quando se elegeu para estudo o gênero Lasiodera Gray, 1832, o mesmo estava representado por 14 espécies, sendo 13 assinaladas para o Brasil e uma para o México (RACCA Filho \& SANTos 1988), entretanto a análise dos caracteres morfológicos e de genitália dos machos permitiu dividi-lo em dois, o que levou a revalidar o gênero Philyra Laporte, 1836. Tais estudos foram feitos unicamente por RACCA FILHO \& SANTOS (1988) que abordaram as genitálias de Lasiodera jucunda (Schenkling, 1900) e L. basalis Racca Filho \& Santos, 1988.

Aqui analisa-se as estruturas das genitálias dos machos de Lasiodera Gray e Philyra Laporte, na tentativa de encontrar novos elementos morfológicos aplicáveis à sistemática dos gêneros e também são feitas redescrições pormenorizadas das espécies, objetivando um melhor conhecimento das mesmas.

\section{MATERIAL E MÉTODOS}

Foram examinados 208 exemplares das seguintes coleções, cedidos por empréstimo pelos pesquisadores cujos nomes aparecem entre parênteses: ALP Adriano Lucio Peracchi, Universidade Federal Rural do Rio de Janeiro (A.L.

1) Instituto de Biologia, Universidade Federal Rural do Rio de Janeiro. 23851-970 Seropédica, Rio de Janeiro, Brasil.

2) Bolsista do CNPq 
Peracchi); CACS - Carlos Alberto Campos Seabra, Museu Nacional, Rio de Janeiro (C.A.C. Seabra); FMNH - Field Museum of Natural History, Chicago (H. Dibas); GW - Gregório Williner, Colégio S. Miguel, Argentina (G. Williner); HZ - Herman Zellibor, Museu de Zoologia da Universidade de São Paulo (U.R. Martins); IBSP - Instituto Biológico, São Paulo (J. Pinto da Fonseca); IEEA - Instituto de Ecologia e Experimentação Agrícolas, Museu Nacional, Rio de Janeiro (B.A.M. Soares); IOC - Instituto Oswaldo Cruz, Rio de Janeiro (J. Jurberg); JFZ - J.F. Zikán, atualmente depositada na Coleção do Instituto Oswaldo Cruz, Rio de Janeiro (J. Jurberg); MNRJ - Museu Nacional, Rio de Janeiro (J. Becker) e MZSP - Museu de Zoologia da Universidade de São Paulo (U.R. Martins).

Também teve-se oportunidade de examinar fotografias de material depositado no The Natural History Museum, London, de Lasiodera kirbyi Gray, 1832, L. trifasciata (Laporte, 1836), L. rufipes (Klug, 1842) e do material tipo de L. ruficollis (Gorham, 1877).

Para o estudo morfológico das genitálias dos machos utilizou-se a técnica de montagem preconizada por CosTA LiMA (1921) e na análise e nomenclatura das peças optou-se pelos sistemas de SHARP \& MUIR (1912) e de JEANNEL \& PAULIAN (1944).

As medidas, em milímetros, referem-se às seguintes especificações: comprimento total do corpo (do ponto de maior aproximação dos olhos até a extremidade apical do élitro); maior largura do protórax; comprimento do protórax; largura umeral (na altura dos calos umerais) e comprimento do élitro. Lasiodera ornata (Klug, 1842) e L. voluptuosa (Thomson, 1860) não estavam representadas nas coleções estudadas. Os dados referentes à morfologia das mesmas, utilizados na chave para separação das espécies, foram obtidos das descrições originais.

Os dados referentes à distribuição geográfica das espécies referem-se àqueles do material examinado, como também os obtidos através da literatura. Os dados relativos à localidade tipo são aqueles obtidos através das descrições originais.

\section{HISTÓRICO}

O nome Lasiodera aparece pela primeira vez em 1832 quando GRAY descreveu a espécie Clerus kirbyi, pois ao ilustrá-la nomeou-a Lasiodera kirbyi.

LAPORTE (1836), analisando duas espécies de clerídeos do Brasil, descreveu-as em gêneros distintos. Para uma delas criou o gênero Philyra, nomeando-a $P$. helopioides, e a outra foi descrita como Clerus trifasciatus.

SPINOLA (1844) criou o gênero Pelonium, anagrama de Enoplium Latreille, 1802, para comportar as espécies de Enoplium do Novo Mundo. Naquela ocasião não considerou o gênero criado por Laporte, sinonimizando Philyra helopioides com Enoplium pulchellum Dejean, 1837.

Quando Chevrolat (1876) descreveu Pelonium semivittatum, mais tarde sinonimizada com Pelonium helopioides (Laporte, 1836), já mencionava o fato de que esta espécie deveria formar, junto com $P$. stenochioides Chevrolat, 1874, um grupo dentro do gênero Pelonium Spinola, 1844, devido às suas características morfológicas.

Devido à complexidade do gênero Pelonium, GaHAN (1910) subdividiu-o 
em três. Essa divisão foi feita levando em conta, principalmente, a granulação dos olhos e tipo de unhas. Para um dos gêneros foi revalidado o nome Lasiodera Gray, 1832, que passou a contar com as espécies de Pelonium que possuíam olhos com pequenas facetas e unhas simples.

\section{RESULTADOS E DISCUSSÃO}

Embora todas as espécies hoje pertencentes ao gênero Lasiodera se enquadrem nos caracteres propostos por GAHAN (1910), a análise do conjunto mostrou características na morfologia externa e nas genitálias dos machos que permitem concluir que tem-se dois grupos distintos. Assim, um grupo de espécies apresenta pronoto lateralmente tuberculado no terço posterior e antenas dos machos semelhantes às das fêmeas, enquanto que outro grupo apresenta pronoto ligeiramente convexo com bordos externos subparalelos e antenas dos machos com os dois primeiros artículos da clava expandidos na base e nas fêmeas subtriangulares. Essa separação foi corroborada pela análise das genitálias dos machos onde no primeiro grupo os lobos laterais, com longos pêlos marginais nos ápices, são unidos ventralmente por uma membrana na metade basal; o lobo mediano é membranoso, sustentado por um par de estruturas esclerotinizadas ("median struts" de SHARP \& MUIR 1912), enquanto no segundo grupo os lobos laterais, com pêlos curtos densamente distribuídos no quarto apical, não são unidos ventralmente por uma membrana basal e o lobo mediano é esclerotinizado, com o ápice acuminado.

Ressalta-se que GAHAN (1910), quando revalidou o gênero Lasiodera, assim como CORPORAAL (1948), ao adicionar outras espécies ao gênero, somente se referiram às espécies com pronoto tuberculado no terço posterior, já que provavelmente não tinham conhecimento das demais espécies não possuidoras de tal caráter.

Baseado nestas características julga-se conveniente propor a divisão do gênero Lasiodera em dois gêneros distintos: Lasiodera Gray para o primeiro grupo citado, sendo que para o segundo grupo revalida-se o gênero Philyra Laporte, cuja espécie tipo é Philyra helopioides Laporte, 1836. Apesar de não ter em mãos nenhum exemplar macho desta espécie, impossibilitando a análise da genitália e antenas, o exemplar fêmea observado tem características morfológicas semelhantes às das outras espécies, cujas genitálias dos machos foram analisadas.

Estes gêneros são muito próximos de Corinthiscus Fairmaire \& Germain, 1861 e Cregya Leconte, 1861, deles se distinguindo por apresentarem olhos com pequenas facetas e unhas simples, enquanto Corinthiscus e Cregya têm olhos com grandes facetas, sendo as unhas simples em Corinthiscus e pedunculadas em: Cregya.

\section{Lasiodera Gray, 1832}

Lasiodera Gray, 1832, pr. 48, fig. 3. -Gahan, 1910: 75. - Schenkling, 1910: 127. - Blackwelder, 1945: 390. - Corporaal, 1948: 245. - Corporaal, 1950: 278

Pelonium (partim) Spinola, 1844: 154, 362. - Lacordaire, 1857: 480. - Gemminger \& Harold, 1869: 1754. - Gorham, 1877: 419. - Schenkling, 1903: 106

Laciodera (sic): Bruch, 1915: 253 
Redescrição. Cabeça: olhos com pequenas facetas, emarginados frontalmente, largamente separados tanto em cima como na fronte; fronte mais longa do que larga; labro invaginado medianamente, com os bordos laterais arredondados; mandíbulas desenvolvidas, recurvadas, expandidas na base, com a face externa escavada até próximo do ápice, este acuminado; palpos maxilares e labiais com os últimos artículos securiformes (Figs 2-3); antenas de onze artículos, com os três últimos formando clava com os dois primeiros de forma subtriangular e o terceiro oval, semelhante em ambos os sexos, mais longas que a cabeça e o protórax em conjunto (Fig. 1).

Tórax. Bordo posterior do pronoto rebordado; tuberculado lateralmente no terço posterior; ângulos anteriores arredondados e posteriores quase retos. Escutelo subtriangular. Tarsos criptopentâmeros, com os três primeiros artículos expandidos ventralmente, o quarto muito curto e o quinto alongado; unhas simples com um leve intumescimento na base; acetábulos das coxas anteriores abertos atrás; fêmures engrossados; tíbias delicadas e um tanto arqueadas.

Élitros alongados, convexos, envolvendo lateralmente o abdome; úmeros arredondados.

Abdome. Nos machos o bordo posterior do quinto urosternito reentrante, em forma semicircular e nas fêmeas não reentrante (Figs 4-5).

Genitália dos machos - edeago do tipo invaginado. Tégmen com os lobos laterais e a peça basal formando um semi-estojo por onde o lobo mediano se move livremente. Tégmen formado pela peça basal estreita, alongada, ultrapassando o ponto de união com os lobos laterais, com ápice bífido e acuminado e, pelos lobos İaterais arqueados, expandidos para os ápices arredondados. Lobos laterais com pêlos longos, marginais. Dorsalmente os lobos laterais unidos na metade basal e ventralmente unidos por uma membrana. O lobo mediano arqueado, membranoso, sustentado por um par de estruturas esclerotinizadas, com formatos específicos, apicalmente.

Espécie tipo do gênero: Lasiodera kirbyi Gray, 1832.

\section{Chave para as espécies}

1. Pronoto piloso (lanoso); élitros amarelados, com o terço apical preto com duas manchas arredondadas alaranjadas . . . . . . . . . . . . . . . kirbyi

- Pronoto piloso, porém não apresentando o aspecto lanoso; élitros amarelados com três faixas transversais pretas ou violáceas . ................ 2

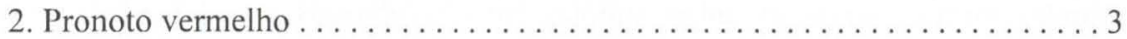

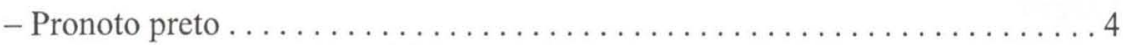

3. Antenas com os artículos da clava esbranquiçados; élitros rugoso pontuados ... ornata

- Antenas com os artículos da clava pretos; élitros finamente pontuados . . ruficollis

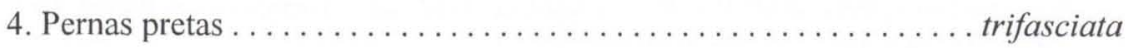

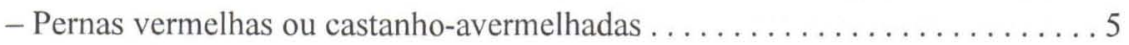

Revta bras. Zool. 13 (2): 357 - 397, 1996 
5. Élitros com as três faixas transversais pretas, sem pontuações profundas; pronoto com uma depressão longitudinal, tarsos pretos . . . . . . . . . . rufipes

- Élitros com pontuações profundas nas faixas transversais; tarsos castanhos . . . .6 6. Élitros com as três faixas transversais pretas, com pontuações profundas nas faixas basal e mediana .......................... zonata

- Élitros com as faixas transversais basal e mediana de cor preta uniforme e a faixa apical lateralmente preta e avermelhada próximo à sutura ...... voluptuosa
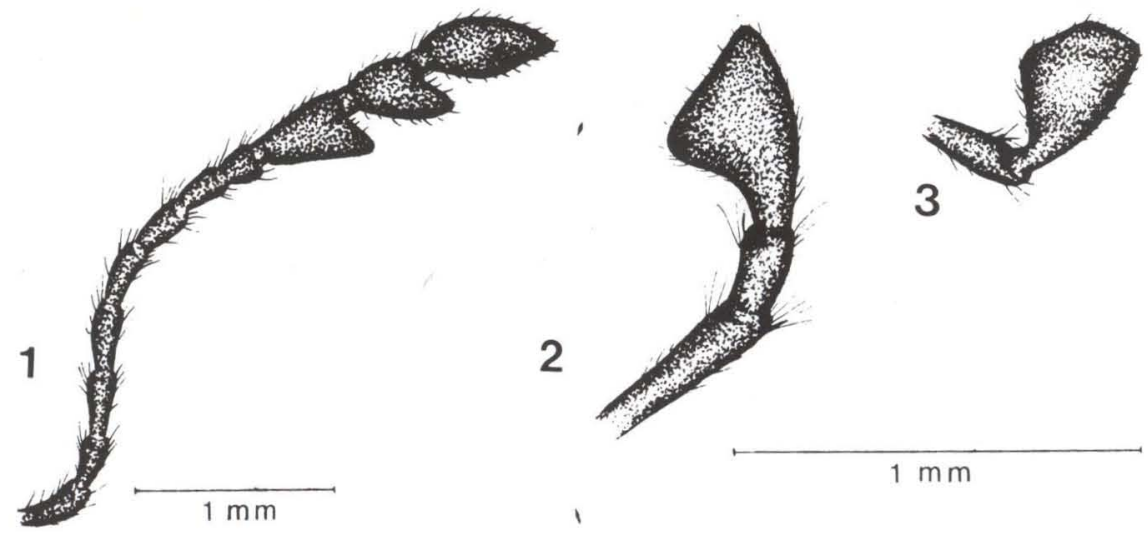

$1 \mathrm{~mm}$

1
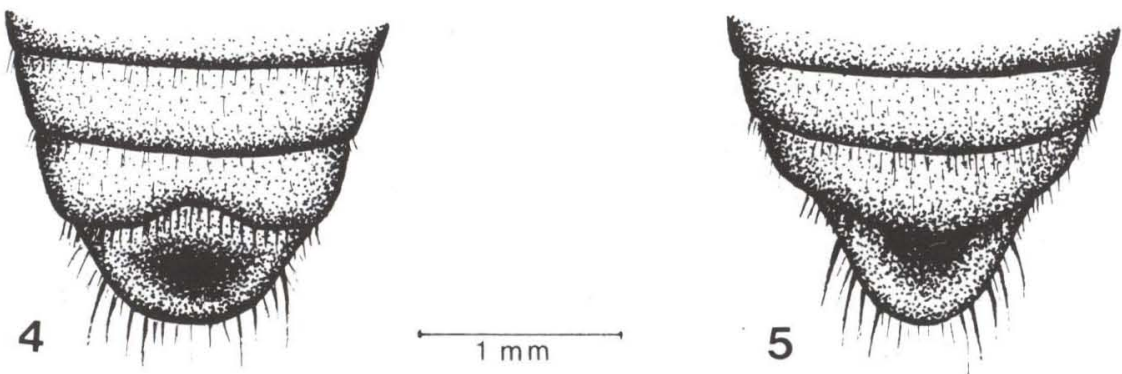

Figs 1-5. Lasiodera ruficollis (Gorham, 1877). (1) Fêmea antena; (2) macho palpo maxilar; (3) Macho palpo labial; (4) macho vista ventral do abdome; (5) fêmea vista ventral do abdome. 


\section{Lasiodera kirbyi Gray, 1832}

Figs 6-12

Clerus kirbyi Gray, 1832: 376

Lasiodera kirbyi Gray, 1832, pl. 48, fig. 3. - Gahan, 1910: 75. - Schenkling, 1910: 127. -Blackwelder, 1945: 390. - Corporaal, 1948: 245. - Costa Lima, 1953: 190, fig. 148. - Corporaal, 1950: 278

Enoplium kirbyi: Klug, 1842: 262. -Spinola, 1844 Supl.: 152

Pelonium kirbyi: Lacordaire, 1857: 480. -Gemminger \& Harold, 1869: 1754. - Schenkling, 1903: 106 Pelonium superbum Lucas, 1857: 94, pr. 5, fig. 3. - Gemminger \& Harold, 1869: 1754

Redescrição. Macho (Fig. 6). Cabeça preta, densamente pontuada e pilosa com pêlos amarelados na fronte e pretos no vértice; clípeo e labro castanhos; mandíbulas, olhos e palpos maxilares e labiais pretos; antenas pretas, pilosas com pêlos esbranquiçados; escapo e pedicelo inferiormente de cor castanha; primeiro artículo do funículo mais longo que os demais; clava com pilosidade também preta, com pêlos mais curtos que aqueles dos demais artículos.

Protórax preto, densamente pontuado e piloso, com pêlos longos, pretos, dando o aspecto lanoso; ângulos anteriores arredondados e posteriores quase retos; ligeiramente estrangulado na base; bordo anterior pouco mais largo que o posterior. Escutelo preto, com pontos pilosos.

Pernas pretas, densamente pilosas com longos pêlos amarelados; expansões dos três primeiros tarsômeros castanhas ventralmente; unhas castanhas.

Élitros amarelados, com o terço apical, sutura e duas faixas pretas; faixa anterior em forma de meia lua, estreita, arqueada para trás, não atingindo a sutura nem a margem; faixa posterior em forma de "V", com o vértice voltado para a base, partindo da margem e atingindo a sutura, onde une-se ao terço apical por estreita área preta; terço apical com duas manchas arredondadas, alaranjadas; terço anterior e mediano com inúmeros pontos enegrecidos de formas e profundidades variadas; pilosidade amarelada abundante, excetuando-se nas áreas pretas, onde os pêlos também são pretos.

Abdome castanho, com pilosidade esbranquiçada.

Genitália (Figs 7-12). Lobos laterais com uma pequena abertura transversal mediana, quando observados lateralmente; terço basal, em vista lateral, com contorno formando ângulo reto no bordo dorsal; em vista dorsal unidos no quarto basal e estreitamente aproximados até próximo à metade, quando então se afastam; ápices largamente afastados. Lobo mediano, em vista lateral, comprimido próximo ao ápice, assumindo uma forma espatular e terminando em ponta levemente encurvada; bífido no ápice.

Fêmea semelhante ao macho.

Dimensões (mm). Macho: Comprimento total, 13,1; comprimento do protórax, 3,6; largura do protórax, 3,4; comprimento do élitro, 8,6; largura umeral, 3,6. Fêmea: comprimento total, 15,4; comprimento do protórax, 4,2; largura do protórax, 4,1; comprimento do élitro, 10,8; largura umeral, 4,4.

Localidade tipo: BRASIL.

Distribuição geográfica. BRASIL: Minas Gerais.

Material examinado. Brasil, Minas Gerais: Mar de Espanha, 1 fêmea 
14.XI.1910, J.F. Zikán leg. (JFZ); sem procedência, 1 macho 17.XI.1943, sem coletor (JFZ).

Discussão. Esta espécie é facilmente diferenciada das demais, não só por seu colorido, como também por ser a única com o pronoto densamente piloso, com aspecto lanoso.

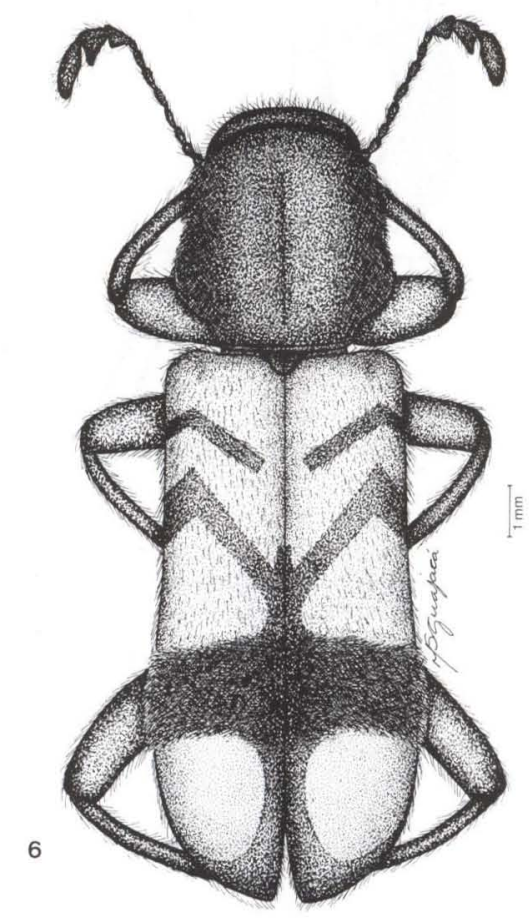

Fig. 6. Lasiodera kirbyi Gray, 1832, macho vista dorsal.

\section{Lasiodera ruficollis (Gorham, 1877)}

Figs $1-5,13-19$

Pelonium ruficolle Gorham, 1877: 419. -Schenkling, 1903: 106.

Lasiodera ruficollis: Gahan, 1910: 75. -Schenkling, 1910: 127. - Blackwelder, 1945: 390. -Corporaal, 1950: 278 .

Lasiodera malleri Pic, 1933: 292. -Blackwelder, 1945: 390. - Corporaal, 1950: 278. n.syn.

Redescrição. Macho (Fig. 13). Cabeça castanho-avermelhada, com pontos pilosos na fronte; olhos pretos com reflexos avermelhados; mandíbulas castanhoavermelhadas com os ápices pretos; palpos maxilares e labiais castanhos; antenas (Fig. 1) pilosas com os oito primeiros artículos castanho-avermelhados e os três últimos formando clava, pretos, sendo os dois primeiros de forma subtriangular e o último oval terminando em ponta levemente pronunciada. 

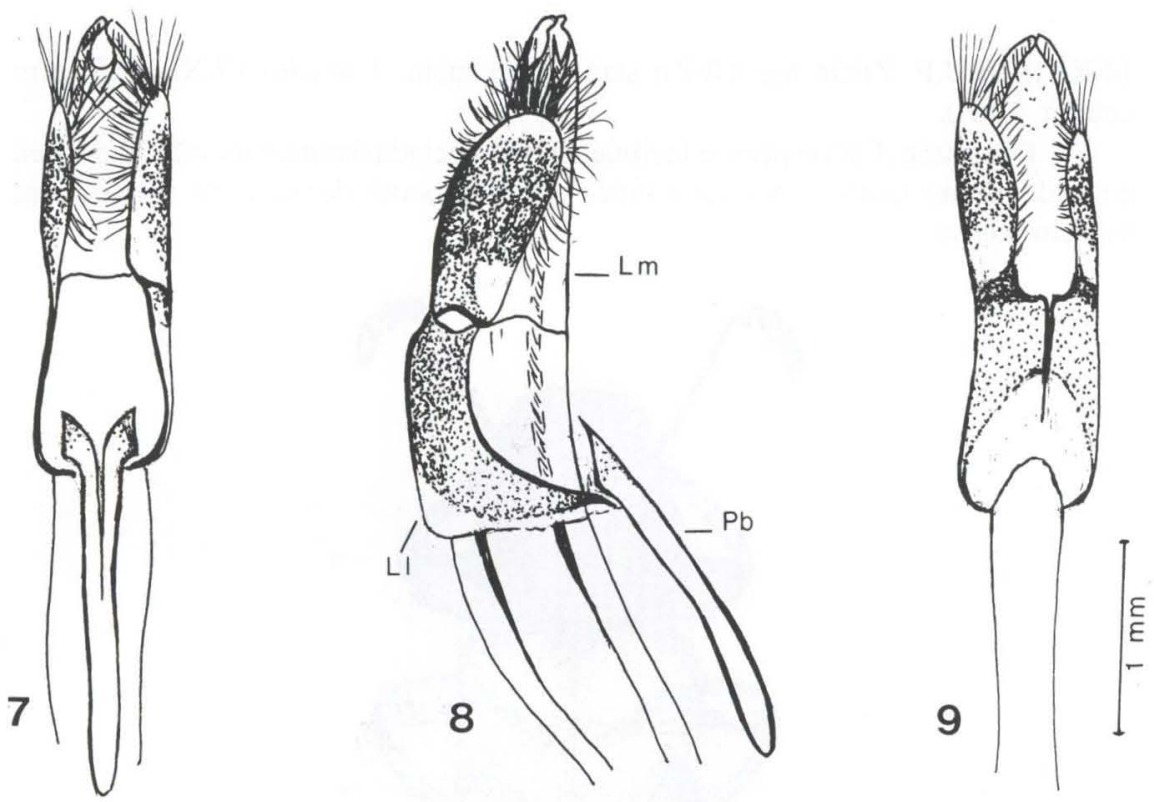

Figs 7-9. Lasiodera kirbyi Gray, 1832, edeago. (7) Vista ventral; (8) vista lateral; (9) vista dorsal.

Protórax fortemente convexo, castanho-avermelhado, com pontos pilosos uniformemente distribuídos. Face ventral castanho-avermelhada. Escutelo castanho-avermelhado.

Pernas castanho-avermelhadas, pilosas; unhas um tanto mais escuras.

Élitros pilosos, amarelo-sulfúreos com pontos pilosos pretos, três faixas transversais, sutura, bordos laterais e ápices pretos com reflexos violáceos; a primeira faixa deixa sobre a base uma mácula transversal afastada do bordo; as outras contínuas estendendo-se da margem até a sutura.

Abdome castanho-avermelhado, com pilosidade esparsa esbranquiçada, mais concentrada nos bordos laterais.

Genitália (Figs 14-19). Peça basal, no ponto de união com os lobos laterais, bífida e fortemente acuminada. Lobos laterais unidos dorsal e ventralmente até um pouco além da metade basal, largamente separados nos ápices; lateralmente com uma sutura transversal, um pouco acima do meio, que não atinge toda a extensão. Lobo mediano, em vista ventral, com ápice bífido e dorsalmente em ponta de contorno arredondado; em vista lateral com uma robusta projeção no terço apical.

Fêmea semelhante ao macho.

Dimensões (mm). Macho (5 exemplares): Comprimento total, 8,7-10,6; comprimento do protórax, 2,2-2,8; largura do protórax, 2,3-3,1; comprimento do élitro, 6,0-7,4; largura umeral, 2,4-3,2. Fêmea (6 exemplares): comprimento total, 7,7-10,7; comprimento do protórax, 2,0-2,6; largura do protórax, 1,9-2,9; comprimento do élitro, 5,5-7,5; largura umeral, 2,1-3,1. 

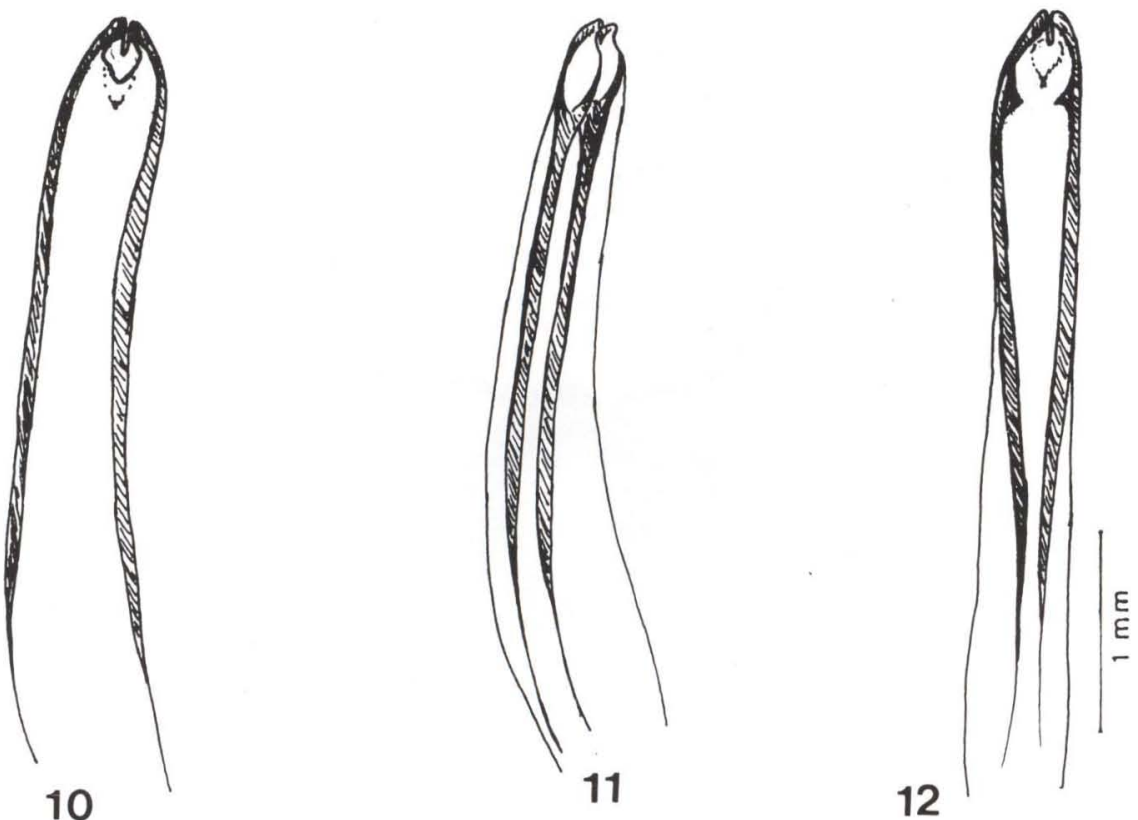

Figs 10-12. Lasiodera kirbyi Gray, 1832 lobo mediano do macho. (10) Vista ventral; (11) vista lateral; (12) vista dorsal. (Pb) Peça basal, (LI) lobo lateral; (Lm) lobo mediano.

Localidade tipo. Brasil, Rio de Janeiro e Paraná.

Distribuição geográfica. BRASIL: Minas Gerais, Rio de Janeiro, São Paulo, Paraná, Santa Catarina.

Material examinado. BRAsiL, Minas Gerais: Passa Quatro (Fazenda dos Campos), 1 macho 26.XI.1914, 1 fêmea 30.XII.1914, 1 macho e 1 fềmea 02.I.1918, 1 macho sem data, J.F. Zikán leg. (JFZ); São Paulo: São Paulo (Cantareira), 1 macho XII.1934, 1 fêmea XI.1941, J. Guerin leg. (MZSP), 1 fêmea 12.XI.1939, H. Zellibor e Hauff leg. (MZSP); (Jabaquara), 1 macho 07.II.1944, H. Zellibor leg. (MZSP); S. José dos Barreiros (Serra da Bocaina), 1 fêmea 31.X.1967, O. Roppa leg. (MNRJ), 1 fềmea XI.1965, Alvarenga e Seabra leg. (CACS).

Discussão. PIC (1933) ao descrever Lasiodera malleri mencionou a semelhança desta espécie com L. ruficollis (Gorham, 1877), ressaltando que a sua espécie possuia os ápices dos élitros orlados de preto e que as faixas transversais eram violáceas, o que a diferenciava da espécie de Gorham. Na análise de fotografias dos síntipos de L. ruficollis depositados no Museu Britânico, observamos que esta espécie também possui os élitros orlados de preto, fato não mencionado na descrição original. No material analisado, os exemplares tanto têm as faixas transversais dos élitros violáceas quanto pretas, variação esta acentuada pela incidência de luz, assim como os ápices dos élitros também orlados de preto. Este mesmo material contém exemplares determinados como L. ruficollis por consagrados especialistas em 
clerídeos, como Corporaal e Schenkling. As localidades dos exemplares tipos são muito próximas já que o de L. malleri é proveniente de Mafra, Santa Catarina e o de L. ruficollis do Paraná e Rio de Janeiro. Com a análise destes dados conclui-se por colocar L. malleri como sinônimo de L. ruficollis.

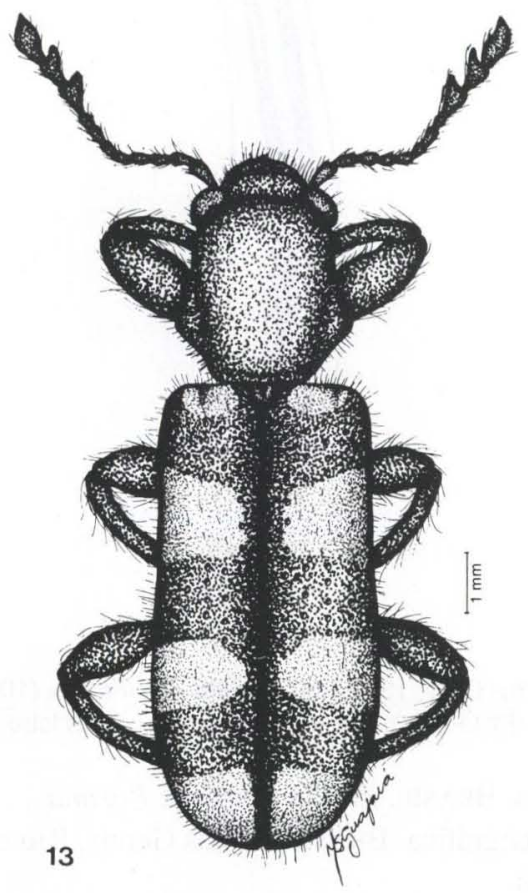

Fig. 13. Lasiodera ruficollis (Gorham, 1877) macho vista dorsal.

Lasiodera rufipes (Klug, 1842)

Figs 20-26

Enoplium rufipes Klug, 1842: 362. -Spinola, 1844: 154.

Pelonium rufipes: Gorham, 1877: 419. -Schenkling, 1903: 106, pl. 2, fig. 11. - Schenkling, 1906: 312. Lasiodera rufipes: Gahan, 1910: 75. -Schenkling, 1910: 127. - Blackwelder, 1945:389. -Corporaal, 1950: 278.

Laciodera (sic) rufipes: Bruch, 1915: 253.

Redescrição. Macho (Fig. 20). Cabeça pilosa, preta; fronte preta com região anterior castanho-avermelhada, densamente pilosa, com pêlos esbranquiçados; clípeo castanho-avermelhado; labro castanho-amarelado; mandíbulas castanhoavermelhadas, com o terço apical enegrecido; palpos maxilares e labiais castanhoamarelados. Antenas pretas, pilosas; escapo castanho-avermelhado, pedicelo curto; três primeiros artículos do funículo cilíndricos, com leve intumescimento no ápice; 
os três artículos seguintes diminuem gradativamente em tamanho; clava constituída de três artículos, sendo o primeiro subtriangular, levemente expandido no ápice; o segundo também subtriangular, mais curto que o anterior, com expansão do ápice mais pronunciada, e o terceiro oval terminando em ponta.
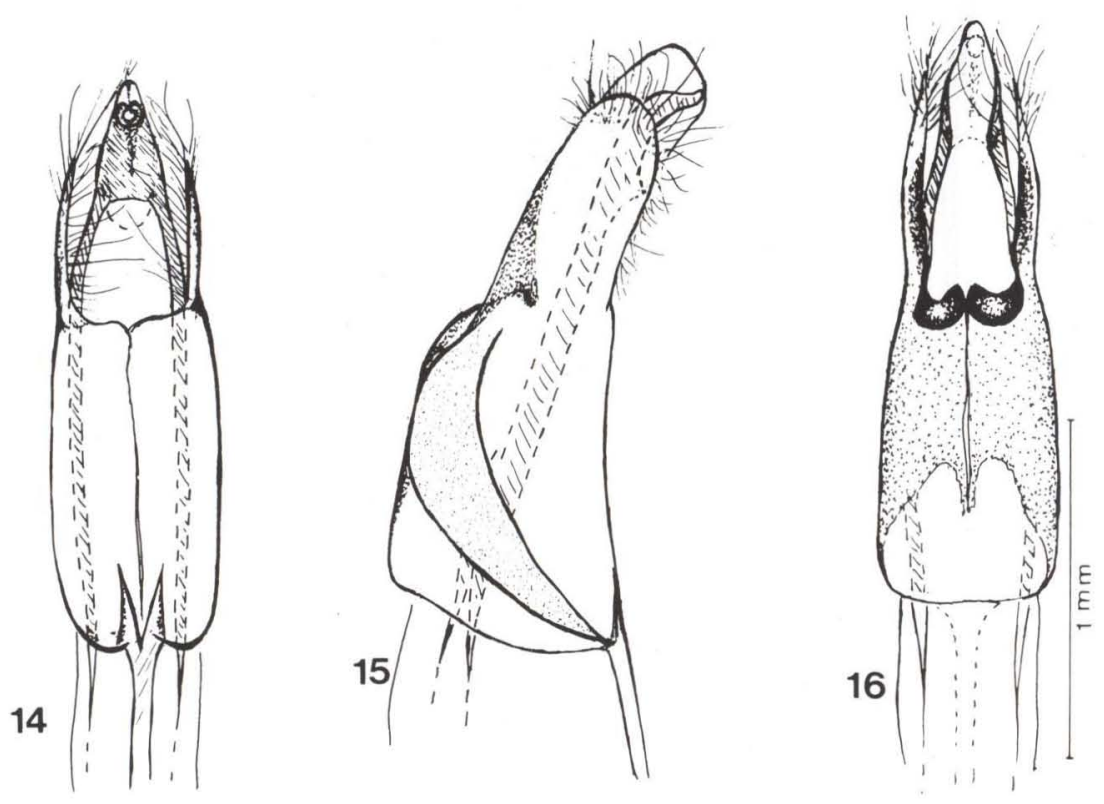

Figs 14-16. Lasiodera ruficollis (Gorham, 1877), edeago. (14) Vista ventral; (15) vista lateral; (16) vista dorsal.

Protórax preto brilhante, piloso, no meio com uma depressão longitudinal; ligeiramente estrangulado na base; bordo anterior pouco mais largo que o posterior. Face ventral do tórax castanho-amarelado, com pontos pilosos.

Pernas vermelhas, pilosas, com pêlos esbranquiçados; tarsos e unhas pretos, o ápice do último artículo tarsal castanho; tíbias com o ápice levemente espessado, na face inferior com dois esporões apicais escurecidos; protíbias com as margens externas serrilhadas.

Élitros pilosos, levemente comprimidos abaixo dos ângulos umerais; subparalelos, estreitando-se próximo ao ápice; ângulo sutural aberto; amarelo-sulfúreos com três faixas transversais e o ápice pretos, sendo a primeira faixa situada logo após a região umeral, estendendo-se da sutura até próximo à margem, mais alargada junto a sutura; faixa mediana estendendo-se da sutura até à margem, com bordos irregulares, com dois estrangulamentos, um próximo à sutura e outro próximo à margem; terceira faixa semelhante à primeira, estendendo-se da sutura à margen, sendo mais larga nos seus extremos, bordos com pequenas irregularidades; sutura preta à partir da faixa mediana, estendendo-se até o ápice, também de cor preta, o qual liga-se marginalmente à faixa transversal posterior. 

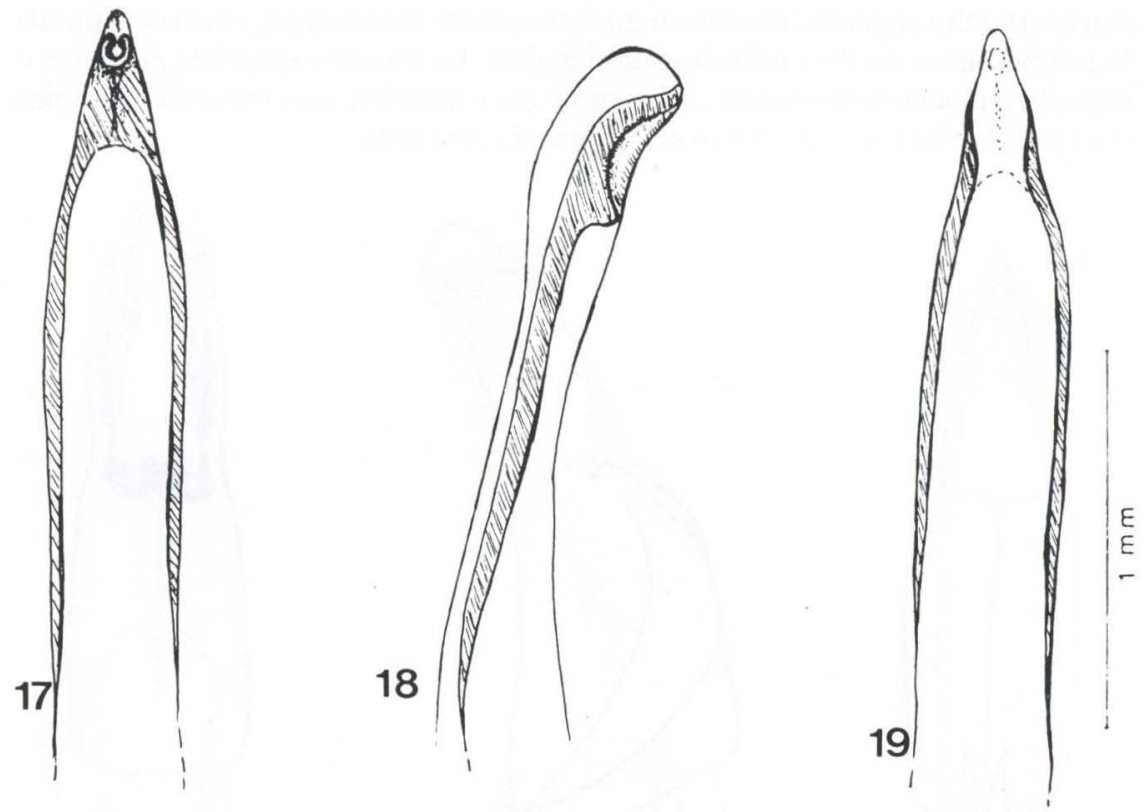

Figs 17-19. Lasiodera ruficollis (Gorham, 1877), lobo mediano do macho. (17) Vista ventral; (18) vista laterả; (19) vista dorsal.

Abdome castanho escuro, com pilosidade esparsa esbranquiçada, mais concentrada nos bordos laterais com pêlos mais longos; urosternitos com uma faixa estreita apical castanho-avermelhada, sem pêlos.

Genitália (Figs 2-26). Lobos laterais com uma pequena abertura transversal mediana, quando observados lateralmente; no dorso, estreitamente aproximados na metade basal, onde se afastam até os ápices, e com dobras pronunciadas das paredes, próximas ao terço apical, que se relacionam com as aberturas visíveis lateralmente. Lobo mediano em vista lateral dilatado no ápice, com uma pequena projeção acuminada; em vista ventral com ápice bífido, de contorno arredondado, com uma abertura subelíptica e uma projeção acuminada para trás, decorrente das dobras das paredes laterais; dorsalmente com ápice bífido.

Fêmea semelhante ao macho.

Dimensões (mm). Macho (14 exemplares): Comprimento total, 12,7-17,6; comprimento do protórax, 3,5-4,8; largura do protórax, 3,1-4,3; comprimento do élitro, 8,7-11,9; largura umeral, 4,0-5,1. Fêmea (3 exemplares): comprimento total, 11,6-15,6; comprimento do protórax, 3,0-4,0; largura do protórax, 2,7-3,8; comprimento do élitro, 8,5-11,2; largura umeral, 3,3-4,6.

Localidade tipo. BRASIL.

Distribuição geográfica. BRASIL: Minas Gerais, Rio de Janeiro, São Paulo; ARgentina: Misiones (BRUCH 1915). 
Material examinado. BRASIL, Minas Gerais: Lavras, 1 macho 20.III.1944, C. Braga leg. (MZSP); Passa Quatro, 3 machos II.1915, J.F. Zikán leg. (IEEA), 1 macho e 1 fêmea 18.XI.1915, J.F. Zikán leg. (JFZ), 1 fêmea 14.XI.1915, J.F. Zikán leg. (JFZ), 1 macho 29.X.1916, J.F. Zikán leg. (IEEA), 1 macho 14.II.1917, J.F. Zikán leg. (JFZ); Poços de Caldas, 1 fềmea 03.II.1968, J. Becker, O. Roppa \& O. Leoncini leg. (MNRJ), 1 macho 26.XI.1969, J. Becker e O. Leoncini leg. (MNRJ); Virginia, 1 macho 17.XII.1920, J.F. Zikán leg. (IBSP); Rio de Janeiro: Itatiaia, 1 macho 06.I.1927, J.F. Zikán leg. (JFZ), 1 macho 28.X.1932, J.F. Zikán leg. (JFZ); Petrópolis, 2 machos sem data, Gagarin leg. (MZSP); São Paulo: Campos do Jordão, 1 macho III.1945, Wygodzinsky leg. (IEEA).

Discussão. Espécie muito próxima de L. zonata, podendo ser separada pela depressão longitudinal do pronoto, pelas faixas dos élitros sem pontuações profundas e pelos tarsos pretos.

\section{Lasiodera trifasciata (Laporte, 1836)}

Figs 27-33

Clerus trifasciatus Laporte, 1836: 47.

Enoplium trifasciatum: Klug, 1842: 362. -Spinola, 1844 Supl.: 152.

Pelonium cleroides Spinola, 1844: 374, Supl.: 152. - Schenkling, 1903: 106.

Pelonium trifasciatum: Spinola, 1844, pl. 34, fig. 3, Supl.: 167. - Lacordaire, 1857: 481. -Desmarest, 1876: fig. 183. - Schenkling, 1903: 106. -Schenkling, 1906: 312.

Enoplium rufipes: Lacordaire, 1857: 481 (nec Klug, 1842).

Pelonium kirbyi: Lacordaire 1876: pl. 46, fig. 5. (nec Gray, 1832).

Lasiodera trifasciata: Gahan, 1910: 75. -Schenkling, 1910: 127. - Blackwelder, 1945: 390. -Corporaal, 1950: 278. - Ekis, 1975: 52.

Redescrição. Macho (Fig. 27). Cabeça pilosa, densamente pontuada, preta, com pêlos esbranquiçados; labro castanho; olhos pretos com reflexos castanhos; palpos maxilares e labiais castanhos, com o último artículo mais escuro, quase preto; antenas pretas, pilosas, sendo a pilosidade dos artículos que formam a clava mais densa e com pêlos mais curtos que aqueles dos demais artículos.

Protórax preto, piloso, pontuado; dorsalmente com uma suave depressão longitudinal ocupando aproximadamente a sua metade anterior; ligeiramente estrangulado na base de modo que o bordo anterior um pouco mais largo que o posterior. Escutelo preto, piloso. Ventralmente preto, com pontos pilosos esparsos.

Pernas pretas, pontuadas, pilosas, com pilosidade esbranquiçada; tarsos pretos, com expansões ventrais dos três primeiros artículos, o ápice do último artículo e as unhas castanhos.

Élitros pontuados, pilosos, com pontos pequenos uniformemente distribuídos; subparalelos, estreitando-se próximo ao ápice; amarelo sulfúreos com três faixas transversais pretas, estendendo-se da sutura até a margem; sutura e o ápice pretos; a primeira faixa situada logo após a região umeral, mais alargada na sutura e estreitando-se gradativamente em direção à margem; a segunda, mediana, mais larga na margem e estreita-se gradativamente em direção à sutura; a terceira faixa, no terço posterior, com a mesma largura em toda extensão. 


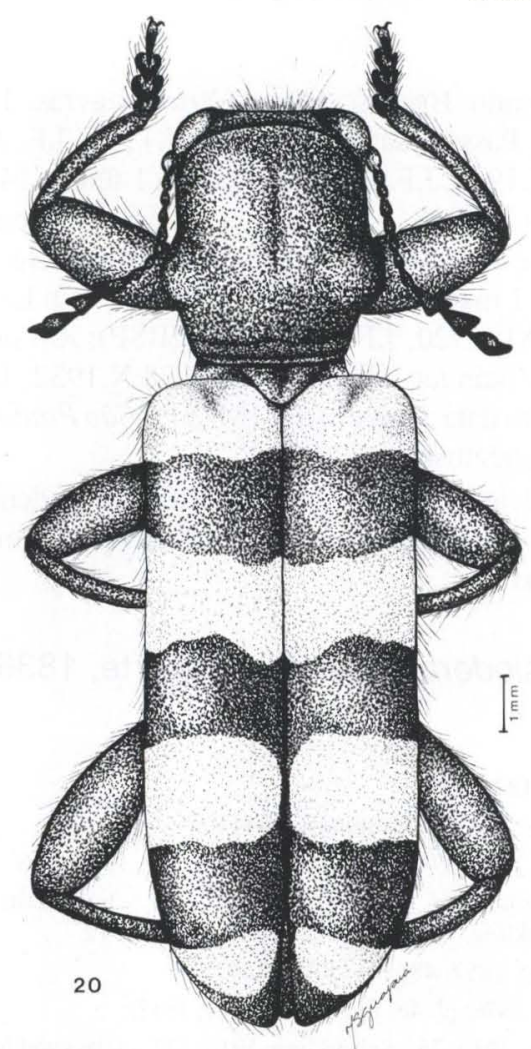

Fig. 20. Lasiodera rufipes (Klug, 1844), macho vista dorsal.

Abdome preto, com pilosidade esparsa esbranquiçada.

Genitália (Figs 28-33). Lobos laterais, dorsalmente, estreitamente aproximados no terço basal e afastados nos ápices; ventralmente, a membrana basal apresenta uma estreita abertura longitudinal em toda sua extensão; lateralmente com uma abertura transversal mediana e com contorno arredondado no bordo dorsal. Lobo mediano em vista lateral com uma expansão apical; em vistas dorsal e ventral com ápice bífido; ventralmente com uma estreita abertura alongada oval no terço apical; dorsalmente com uma projeção, de ápice bífido, decorrente das dobras das paredes laterais.

Fêmea semelhante ao macho.

Dimensões (mm). Macho (7 exemplares): Comprimento total, 13,8-15,6; comprimento do protórax, 3,8-4,2; largura do protórax, 3,6-3,9; comprimento do élitro, 9,6-1 1,0; largura umeral, 4,1-4,5. Fêmea (7 exemplares): comprimento total, 10,9-14,8; comprimento do protórax, 3,1-4,0; largura do protórax, 3,0-3,7; comprimento do élitro, 7,3-10,1; largura umeral, 3,2-4,2.

Localidade tipo. BRAsIL.

Distribuição geográfica. BRASIL: Rio de Janeiro, São Paulo.

Material examinado. BRASIL, Rio de Janeiro: Bocaina, 3 machos e 2 fêmeas 
IV.1924 (MZSP), 1 fêmea IV.1924 (IEEA), 2 machos e 2 fêmeas IV.1924, R. Spitz leg. (IEEA), 1 macho e 1 fêmea IV.1924, Luederwaldt leg. (IEEA); São Paulo: S.J. Barreiros (Serra da Bocaina), 1 macho e 1 fêmea XI.1965, Alvarenga e Seabra leg. (CACS).

Discussão. Esta espécie é facilmente separada das demais por apresentar as pernas de cor preta uniforme.
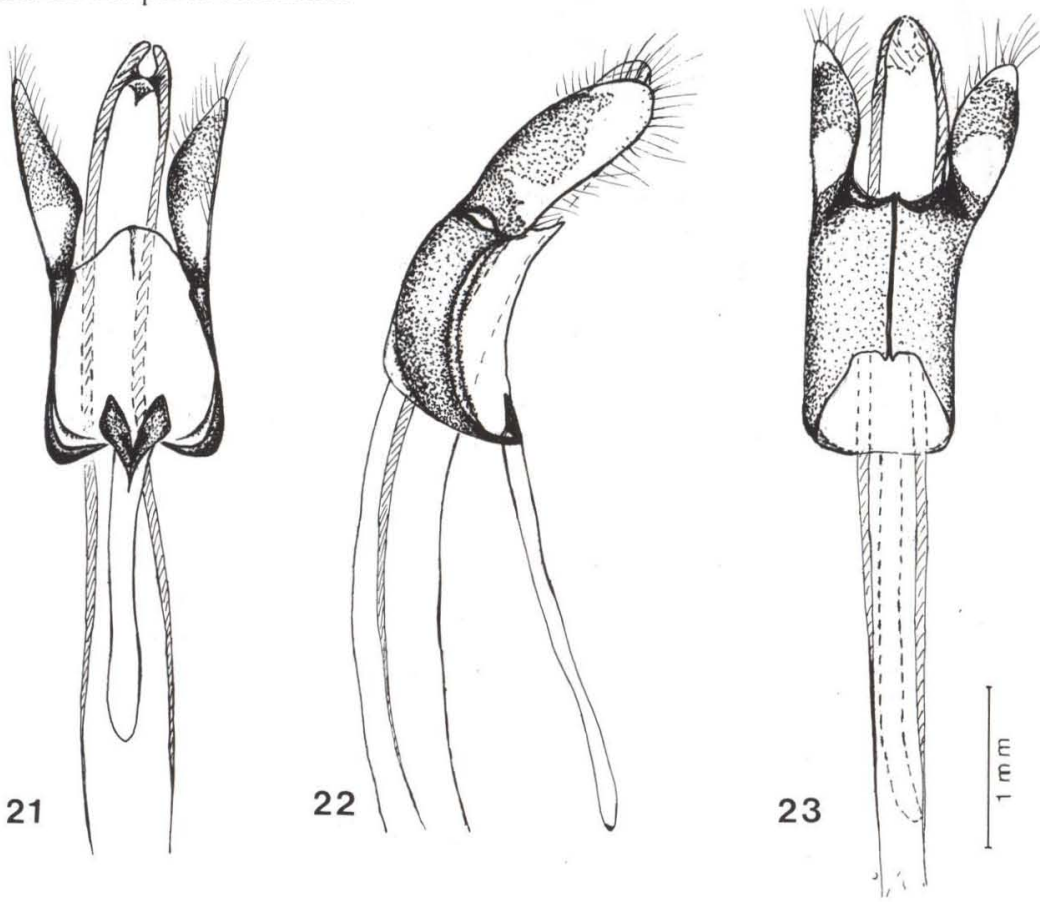

Figs 21-23. Lasiodera rufipes (Klug, 1844), edeago. (21) Vista ventral; (22) vista lateral; (23) vista dorsal.

\section{Lasiodera zonata (Thomson, 1860)}

Figs $34-40$

Pelonium zonatum Thomson, 1860: 66. -Schenkling, 1903: 106. - Schenkling, 1910: 132.

Corinthiscus zonatus: Blackwelder, 1945: 390.

Lasiodera zonata: Corporaal, 1948: 245. -Corporaal, 1950: 279.

Redescrição. Macho (Fig. 34). Cabeça pilosa, densamente pontuada, preta; olhos pretos; fronte preta com a região anterior castanho-amarelada; palpos maxilares e labiais, labro e clípeo castanho-amarelados; mandíbulas castanho-amareladas com o ápice preto; antenas pilosas, escapo e pedicelo castanho-amarelados; os seis segmentos do funículo subcilíndricos, castanho-amarelados, diminuem gradativamente no comprimento; clava preta, com pilosidade abundante, sendo os pêlos menores que aqueles dos demais segmentos. 

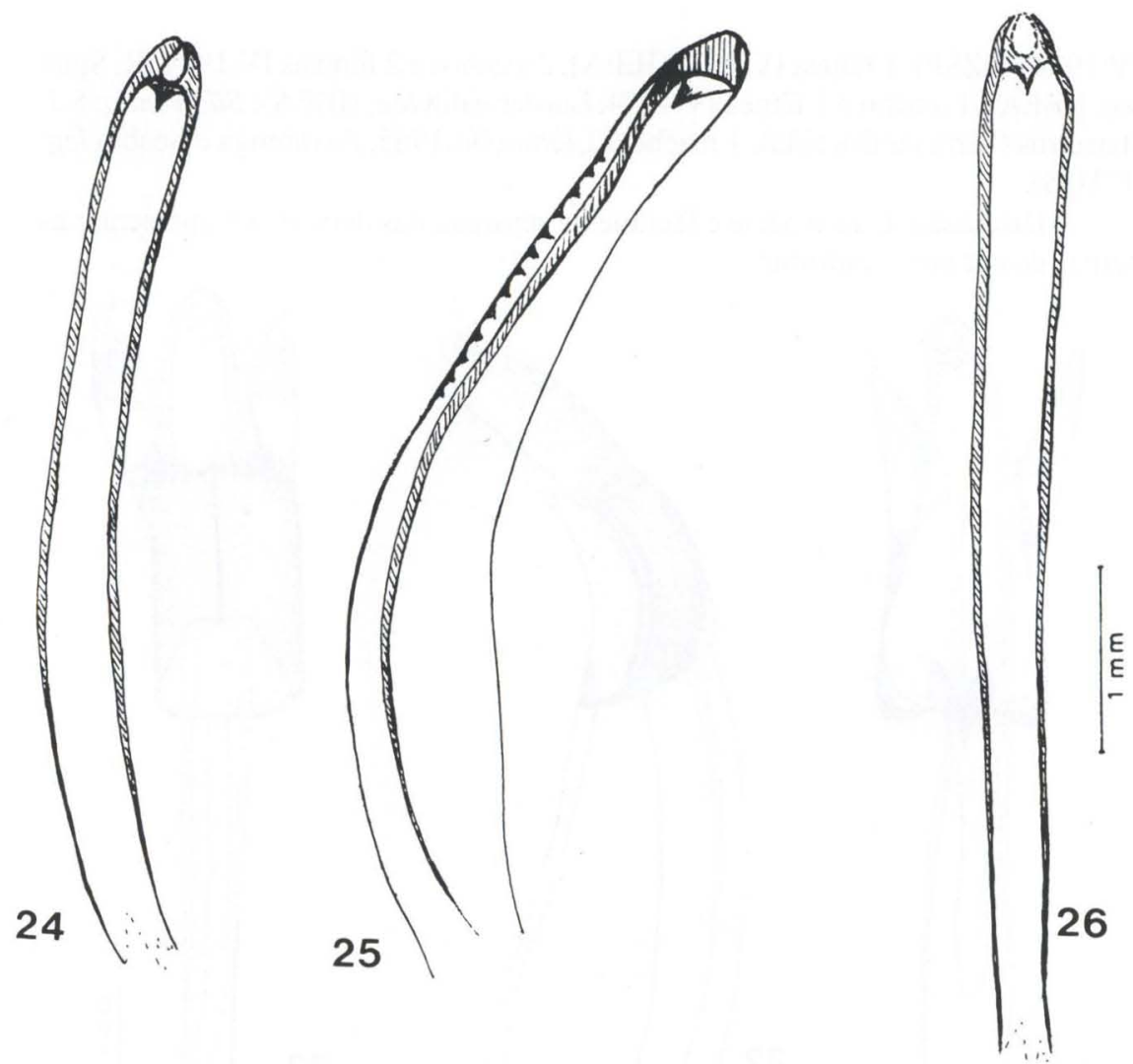

Figs 24-26. Lasiodera rufipes (Klug, 1844), lobo mediano do macho. (24) Vista ventral; (25) vista lateral; (26) vista dorsal.

Protórax densamente pontuado, piloso, preto; ligeiramente estrangulado na base; bordo anterior pouco mais largo que o posterior. Face ventral castanho-amarelada, com pontos pilosos. Escutelo preto.

Pernas castanho-avermelhadas, pilosas, com pilosidade esbranquiçada; tarsos e unhas castanho-avermelhadas.

Élitros amarelos com três faixas pretas irregulares; a faixa anterior próxima à base, partindo da margem e levemente engrossada próximo à sutura; faixa mediana com a margem basal bastante irregular, mais larga na margem e levemente arqueada para o ápice, unindo-se por estreita projeção, na sutura, com a faixa posterior que é levemente arqueada para trás; com pontos profundos, principalmente nas faixas anterior e mediana, próximos à sutura; sutura e ápice pretos.

Abdome preto, piloso, com pilosidade esbranquiçada; urosternitos com uma estreita faixa apical, castanho-avermelhada, sem pêlos.

Genitália (Figs 35-40). Lobos laterais, em vista lateral, com uma sutura mediana, transversal, fortemente marcada; em vista dorsal unidos na metade basal, 
com uma sutura sutil, longitudinal, que não ocupa toda a sua extensão; afastados nos ápices, com uma dobra fortemente evidenciada nos pontos onde estão separados, acima da metade basal; ventralmente unidos pela membrana basal, sutilmente marcada no meio, no sentido longitudinal. Lobo mediano, em vista lateral, com o ápice acuminado e com uma projeção logo abaixo, decorrente das dobras das paredes laterais, observadas ventralmente; em vista ventral com o ápice estreitamente unido e em vista dorsal, também unido pelas dobras apicais das paredes laterais.

Fêmea semelhante ao macho.

Dimensões (mm). Macho (36 exemplares): Comprimento total, 8,2-16,3; comprimento do protórax, 2,3-4,7; largura do protórax, 2,1-3,9; comprimento do élitro, 5,4-11,1; largura umeral, 2,3-4,2. Fêmea (40 exemplares): comprimento total, 9,4-13,6; comprimento do protórax, 2,4-3,6; largura do protórax, 2,2-3,4; comprimento do élitro, 6,3-9,5; largura umeral, 2,5-3,8.

Localidade tipo. BRASIL.

Distribuição Geográfica. BRASIL: São Paulo, Paraná, Santa Catarina, Rio Grande do Sul; Argentina: Misiones; PARAguai.

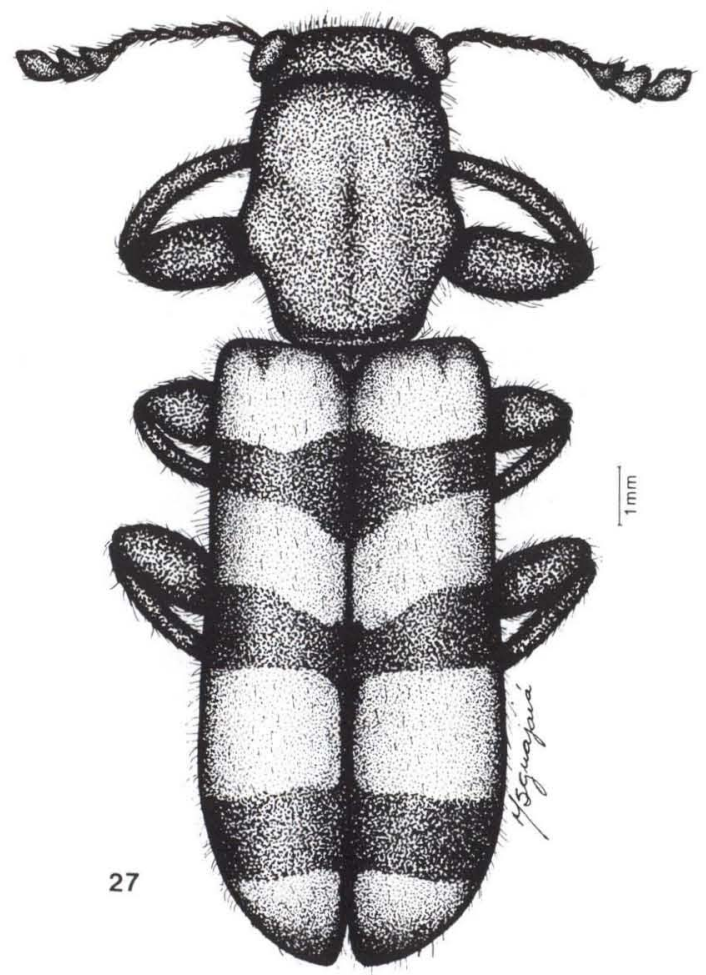

Fig. 27. Lasiodera trifasciata (Laporte, 1836), macho vista dorsal. 

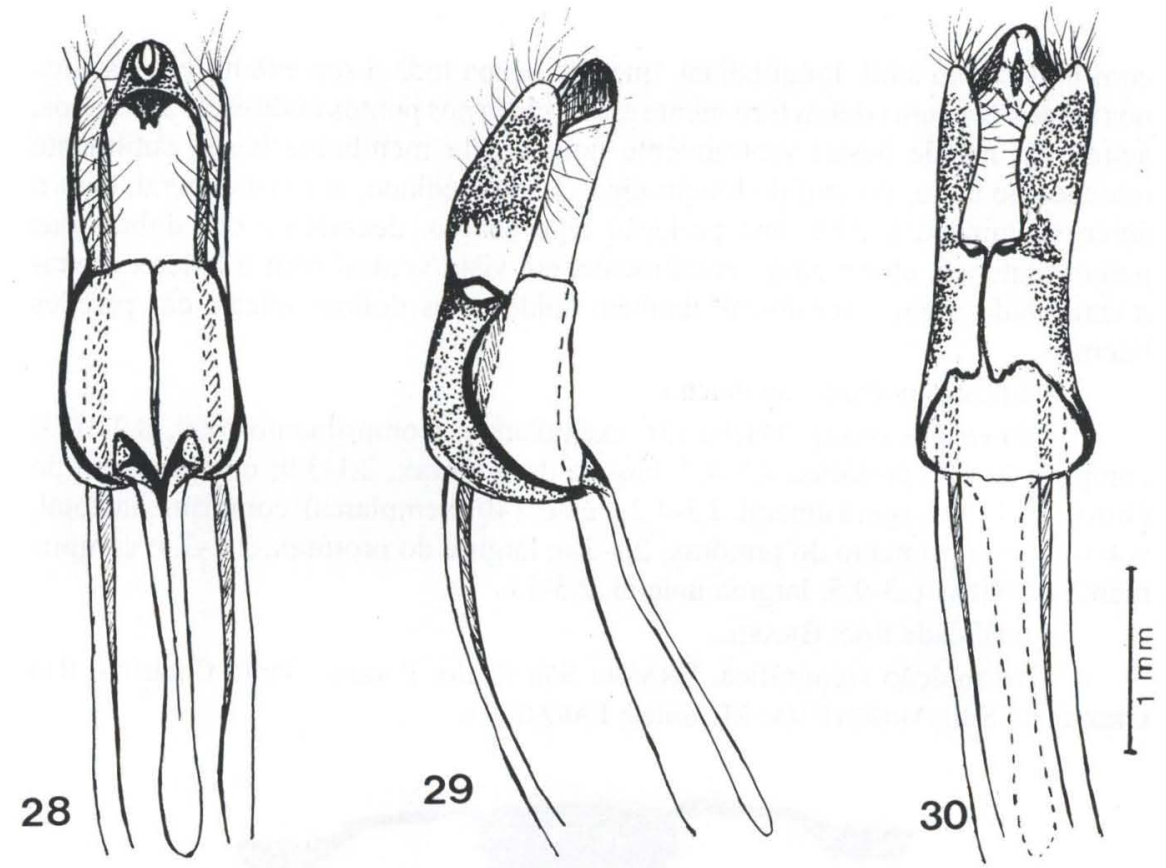

Figs 28-30. Lasiodera trifasciata (Laporte, 1836), edeago. (28) Vista ventral; (29) vista lateral; (30) vista dorsal.

Material examinado. ARgENTINA, Misiones: Puerto Iguazu, 1 macho I.1944, A. Bridarolli leg. (GW); S. Antonio, 1 fêmea X.1958, A. Martinez leg. (CACS). Brasil, São Paulo: Casa Grande, 1 fêmea IV.1935, J. Guerin leg. (IBSP), Indiana, 2 fêmeas 30.X.1934, (HZ), Porto Cabral, 1 macho 15/30.X.1941, L. Travassos Filho leg. (MZSP); Paraná: Arapongas, 1 macho II.1952, A. Maller leg. (CACS), Curitiba, 1 macho I.1938, (IBSP), Londrina, 1 macho I.1934, (IBSP), Ponta Grossa, 1 fêmea 05.XII.1938, 1 fêmea 17.I.1939, Camargo leg. (MZSP), Rondon, 1 fềmea 30.VIII.1952, 1 fêmea 05.IX.1952, 1 fêmea 07.IX.1952, 1 fêmea 08.IX.1952, 1 fềmea 11.IX.1952, 1 fềmea 12.IX.1952, 1 fêmea 26.X.1952, 1 macho 03.XI.1952, 1 fêmea 18.XI.1952, F. Plaumann leg. (FMNH), Santa Mariana, 1 fêmea, H.Zellibor leg. (HZ); Santa Catarina: Corupá (ex Hansa Humboldt), 1 fêmea XI.1939, (HZ), Mafra, 1 fềmea XII.1939, 2 machos e 1 fềmea XII.1939, 2 machos e 1 fêmea I.1940, A. Maller col. (CACS), Seara (Nova Teutônia), 1 macho e 1 fêmea XI.1936 (HZ), 1 macho II.1940, (IBSP), 1 macho III.1941, (MZSP), 1 macho 1942, F. Plaumann leg. (MZSP), 1 fềmea X.1941, 1 fềmea 06.XII.1950, 1 macho 16.XI1951, 1 fềmea 06.XII.1951, 1 macho 14.XII.1951, 1 fềmea 20.XII.1951, 1 fềmea 17.XI.1952, 1 fềmea 23.XII.1953, 1 fềmea 08.IV.1954, 1 macho 01.XII.1954, F. Plaumann leg. (FMNH), 3 fềmeas XI.1961, 2 machos e 1 fềmea X.1962, 6 machos e 2 fềmeas XI.1962, 1 macho e 1 fêmea 03.XI.1962, 2 machos 09.XI.1962, 1 fêmea 29.XI.1962, 2 machos e 1 fêmea 05.XII.1962, 1 fềmea 17.VII.1963, 1 macho 08.III.1964, F. Plaumann leg. (FMNH), S. Bento do Sul (Rio Vermelho), 1 macho III.1939, A. 
Maller leg. (CACS); Rio Grande do Sul: Marcelino Ramos, 1 fêmea XII.1939, (MZSP), 1 macho 15.X.1939, (MZSP), S. Francisco de Paula, 1 macho I.1937, P. Buck leg. (JB). PARAGuaI: S. Barbara, 1 macho e 1 fềmea 17.X.1924, F. Schade leg. (JFZ); San Pedro: S. Estanislao, 1 fêmea I.1948, G. Williner leg. (GW), sem localidade, 1 macho XII.1926, F. Schade leg. (JFZ).

Discussão. Espécie muito próxima de L. rufipes da qual se distingue pelos seguintes caracteres: pronoto sem depressão longitudinal mediana, tarsos castanhos, faixas pretas transversais dos élitros com pontos profundos.
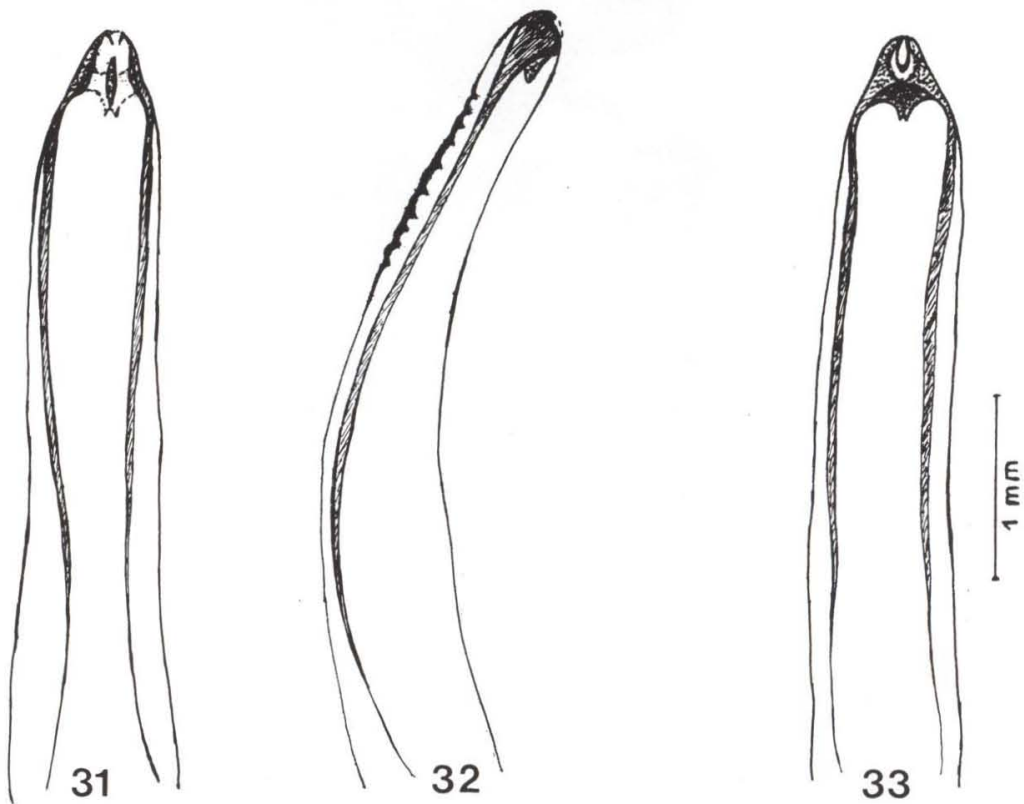

Figs 31-33. Lasiodera trifasciata (Laporte, 1836), lobo mediano do macho. (31) Vista ventral; (32) vista lateral; (33) vista dorsal.

\section{Philyra Laporte, 1836, gen.rev.}

Philyra Laporte, 1836: 53. - Desmarest, 1876: 277.

Pelonium (partim) Spinola, 1844: 377-379. - Lacordaire, 1857: 479. - Gemminger \& Harold, 1869: 1753.

- Schenkling, 1903: 106. - Schenkling, 1910: 130.

Lasiodera (partim): Schenkling, 1910: 127. - Blackwelder, 1945: 390. - Corporaal, 1950: 278.

Corinthiscus (partim): Blackwelder, 1945: 390. - Corporaal, 1950: 288.

Redescrição. Cabeça: olhos com pequenas facetas, emarginados frontalmente, largamente separados tanto em cima como na fronte; fronte mais longa que larga; labro invaginado medianamente com os bordos laterais arredondados; mandíbulas desenvolvidas, recurvadas, expandidas na base, com a face externa escavada até próximo do ápice, este acuminado; palpos maxilares e labiais com os últimos artículos securiformes; antenas de onze artículos, com os três últimos formando 
clava, mais longas que a cabeça e o protórax em conjunto; nos machos os dois primeiros artículos da clava antenal com expansões na base mais longas que o próprio artículo e nas fêmeas de forma subtriangular (Figs 41-42).

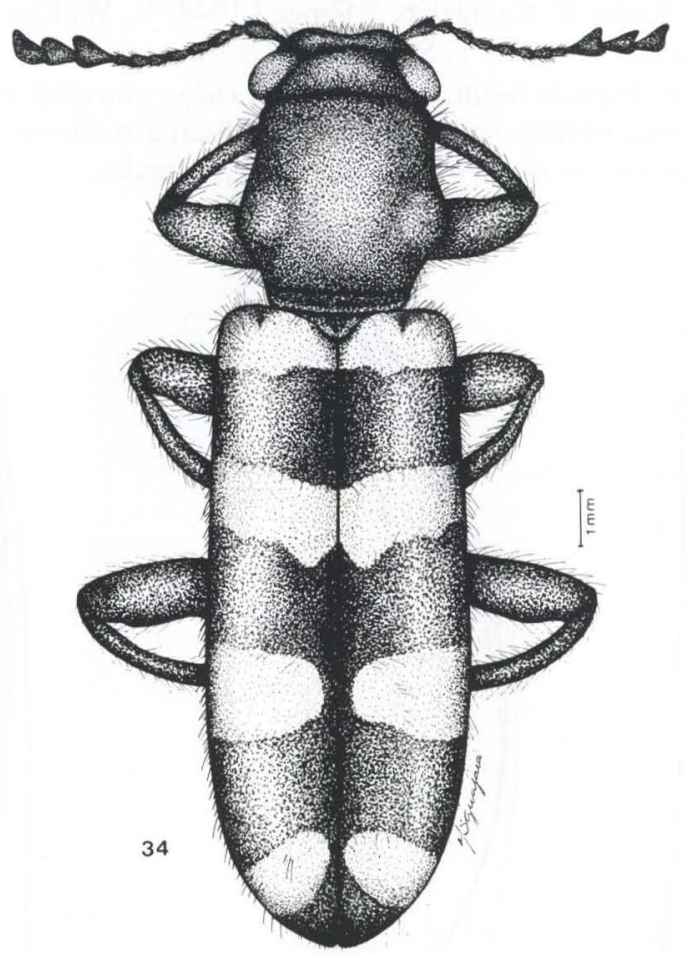

Fig. 34. Lasiodera zonata (Thomson, 1860), macho vista dorsal.

Tórax: ligeiramente convexo; bordo posterior rebordado; bordos externos subparalelos. Tarsos criptopentâmeros, com os três primeiros artículos expandidos ventralmente, o quarto muito curto e o quinto alongado; unhas simples, com um leve intumescimento na base; acetábulos das coxas anteriores abertos atrás.

Abdome: com pilosidade esparsa; bordo posterior do quinto urosternito com uma série de pequenos pêlos em toda extensão, com uma reentrância semicircular nos machos e reto nas fêmeas; urosternitos com uma faixa estreita apical, sem pêlos.

Genitália dos machos - edeago do tipo vaginado. Tégmen formado pela peça basal estreita e alongada e pelos lobos laterais arqueados, expandidos para os ápices arredondados. Quarto apical dos lobos laterais com pêlos curtos, densamente distribuídos. Dorsalmente, os lobos laterais unidos na metade basal e separados nos ápices; ventralmente afastados. O lobo mediano esclerotinizado, com o ápice acuminado e com aberturas ventrais e dorsais de contornos variados; terço apical levemente encurvado. original.

Espécie tipo do gênero. Philyra helopioides Laporte, 1836, por designação 


\section{Chave para as espécies}

1. Coloração geral verde brilhante . ....................... viridis

- Élitros verdes ou violáceos com reflexos metálicos e com desenhos ou faixas

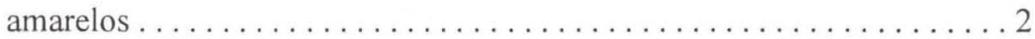

2. Élitros verdes com uma larga faixa basal amarela, ocupando o primeiro quarto e projetando-se junto à margem em ponta até o meio ............ basalis

- Élitros, verdes ou violáceos, com manchas basais cuneiformes ou com faixas

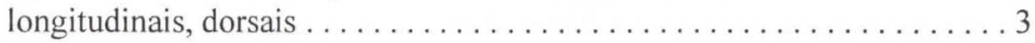

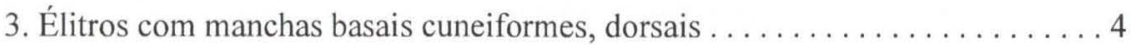

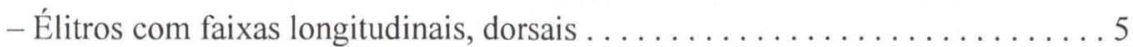

4. Élitros só com faixas longitudinais nas margens, de comprimento aproximado à sua metade .............................. jucunda

- Élitros com faixas longitudinais nas margens, de comprimento aproximado à sua metade, e faixas transversais situadas um pouco além do meio que se estendem da sutura até as margens, onde se unem àquelas longitudinais ...

5. Élitros com faixa longitudinal nas margens, estendendo-se até um pouco além do meio, unida àquela dorsal por uma faixa transversal, também amarela, um tanto inclinada em direção à sutura . . . . . . . . . . . . . . . helopioides

-Élitros com faixa longitudinal nas margens, amarela; faixa dorsal próxima à sutura estreitando-se progressivamente até próximo ao terço posterior onde volta a se alargar ............................. quadrivittata

\section{Philyra basalis (Racca Filho \& Santos, 1988), comb.n. Figs $43-49$}

Lasiodera basalis Racca Filho \& Santos, 1988: 87.

Redescrição do Holótipo. Macho (Fig. 43). Corpo alongado, piloso, tegumento de brilho metálico esverdeado. Cabeça densamente pontuada, com pêlos castanho escuros, amplamente distribuídos; labro castanho ferrugíneo; palpos maxilares e labiais castanho ferrugíneos, com o ápice do último artículo castanho escuro; antenas pretas com os artículos do funículo diminuindo gradativamente de comprimento da base para o ápice, pilosas com pêlos acinzentados; clava antenal com uma cobertura contínua e sedosa de pêlos curtos e delicados, com pêlos pretos curtos e robustos que sobressaem da cobertura subjacente; olhos pretos, com pêlos eretos castanhos e esparsos; mandíbulas pretas.

Protórax alongado, subcilíndrico, levemente convexo no dorso; pronoto com pilosidade castanho escura esparsa, mais concentrada dos lados; pontuação fina e concentrada, mais esparsa no dorso; margem anterior mais larga do que a posterior; lados levemente reentrantes após os ângulos anteriores, proeminentes medianamente, convergindo para a margem posterior; esverdeado, com reflexos purpúreos ao longo da margem posterior; pro, meso e metasterno esverdeados, com pilosidade 
esbranquiçada, mais concentrada no metasterno. Escutelo esverdeado com a margem posterior arredondada.

Pernas pilosas, esverdeadas, excetuando-se tarsos e unhas castanho escuros.

Élitros alongados, convexos, fortemente comprimidos lateralmente contra o abdome, até próximo ao meio; esverdeados com reflexos purpúreos principalmente na área mediana; larga faixa basal amarela, ocupando o primeiro quarto e projetando-se, junto à margem, em forma de ponta até o meio; pontos profundos e densamente distribuídos em forma de retículo, excetuando-se na faixa basal, aqui mais rasos e esparsos; pilosidade castanho escura, exceto na faixa castanho amarelada, esparsa, exceto no ápice e ao longo das margens, onde é mais densa; calos umerais pouco proeminentes; margens afastando-se gradualmente em direção ao ápice, próximo do qual os élitros atingem sua maior largura, onde convergem abruptamente em arco de círculo.

Abdome esverdeado, piloso, principalmente nas margens posteriores dos urosternitos.
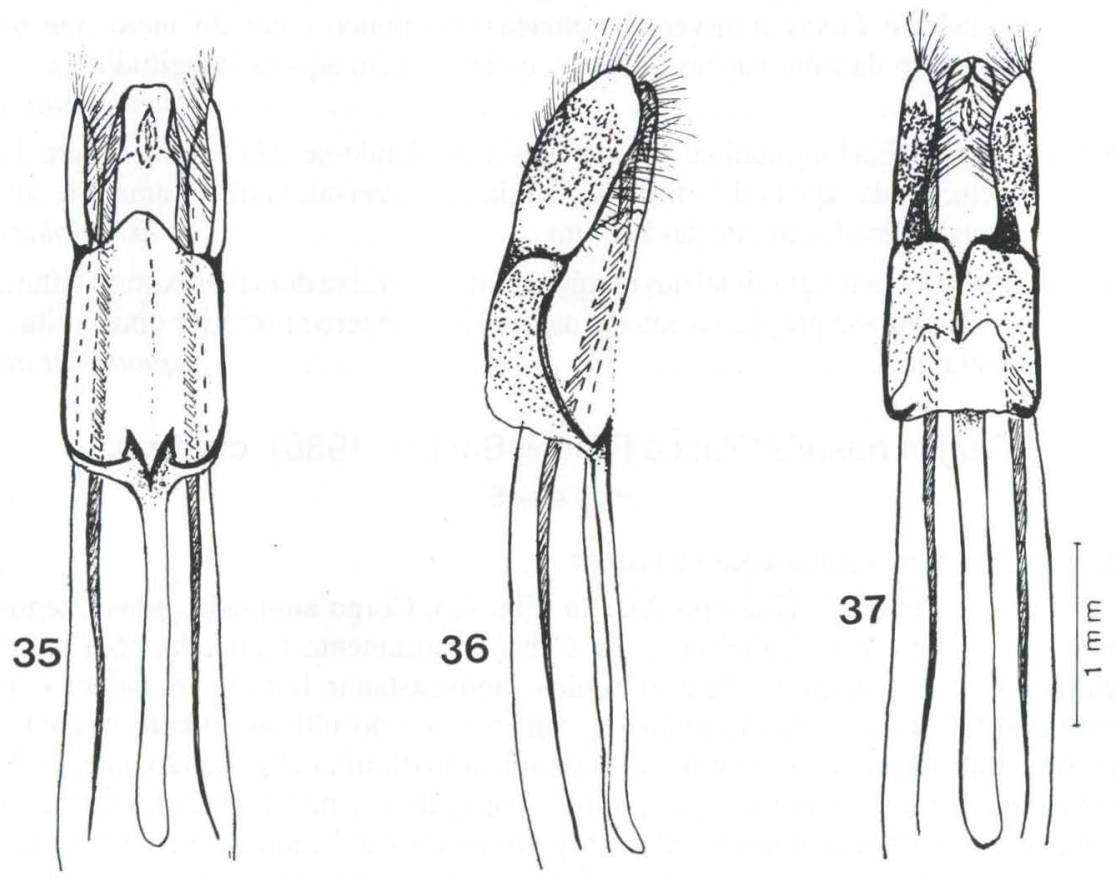

Figs 35-37. Lasiodera zonata (Thomson, 1860), edeago. (35) Vista ventral; (36) vista lateral; (37) vista dorsal.

Genitália (Figs 44-49). Peça basal com ápice ultrapassando o ponto de união com os lobos laterais, bífido em forma de "Y". Lobos laterais largamente unidos dorsalmente, separados no terço apical, com abertura mais acentuada que em $P$. jucunda. Lobo mediano com aberturas dorsal e ventral ocupando quase todo o seu 
comprimento; ventralmente, no terço apical, abertura com contorno triangular e largamente afastados até a base; dorsalmente, abertura com contornos arredondados formando, no terço apical uma abertura subcircular que se liga a uma outra de contorno elíptico, mediana, e a partir desta estreitamente afastado até a base.

Fêmea semelhante ao macho, apresentando-se mais pilosa, com mais reflexos purpúreos no pronoto e nos élitros.

Dimensões $(\mathrm{mm})$. Macho: Comprimento total, 9,0; comprimento do protórax, 2,2; largura do protórax, 2,0; comprimento do élitro, 6,4; largura umeral, 2,8. Fêmea: comprimento total, 8,9; comprimento do protórax, 2,0; largura do protórax, 1,9; comprimento do élitro, 6,5; largura umeral, 2,4.

Localidade tipo. Brasil, Santa Catarina: Seara (Nova Teutônia).

Distribuição geográfica. É conhecida apenas da localidade tipo.

Material examinado. Brasil, Santa Catarina: Seara (Nova Teutônia), 1 macho XI.1938 holótipo, 1 fêmea XII.1937 alótipo, F. Plaumann leg. (FMNH).

Discussão. Espécie afim de $P$. viridis e $P$. jucunda das quais se distingue facilmente pela larga faixa basal amarela nos élitros.
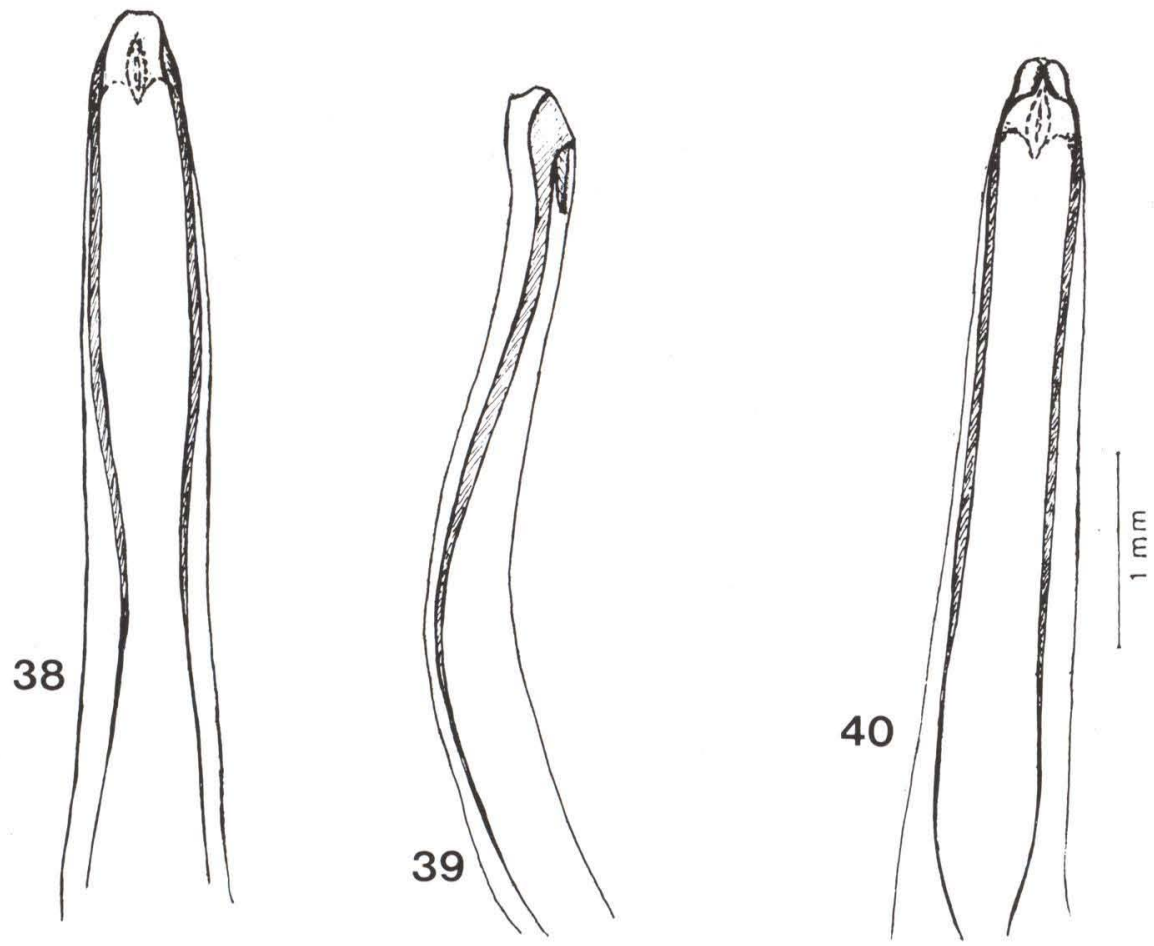

Figs 38-40. Lasiodera zonata (Thomson, 1860), lobo mediano do macho. (38) Vista ventral; (39) vista lateral; (40) vista dorsal. 

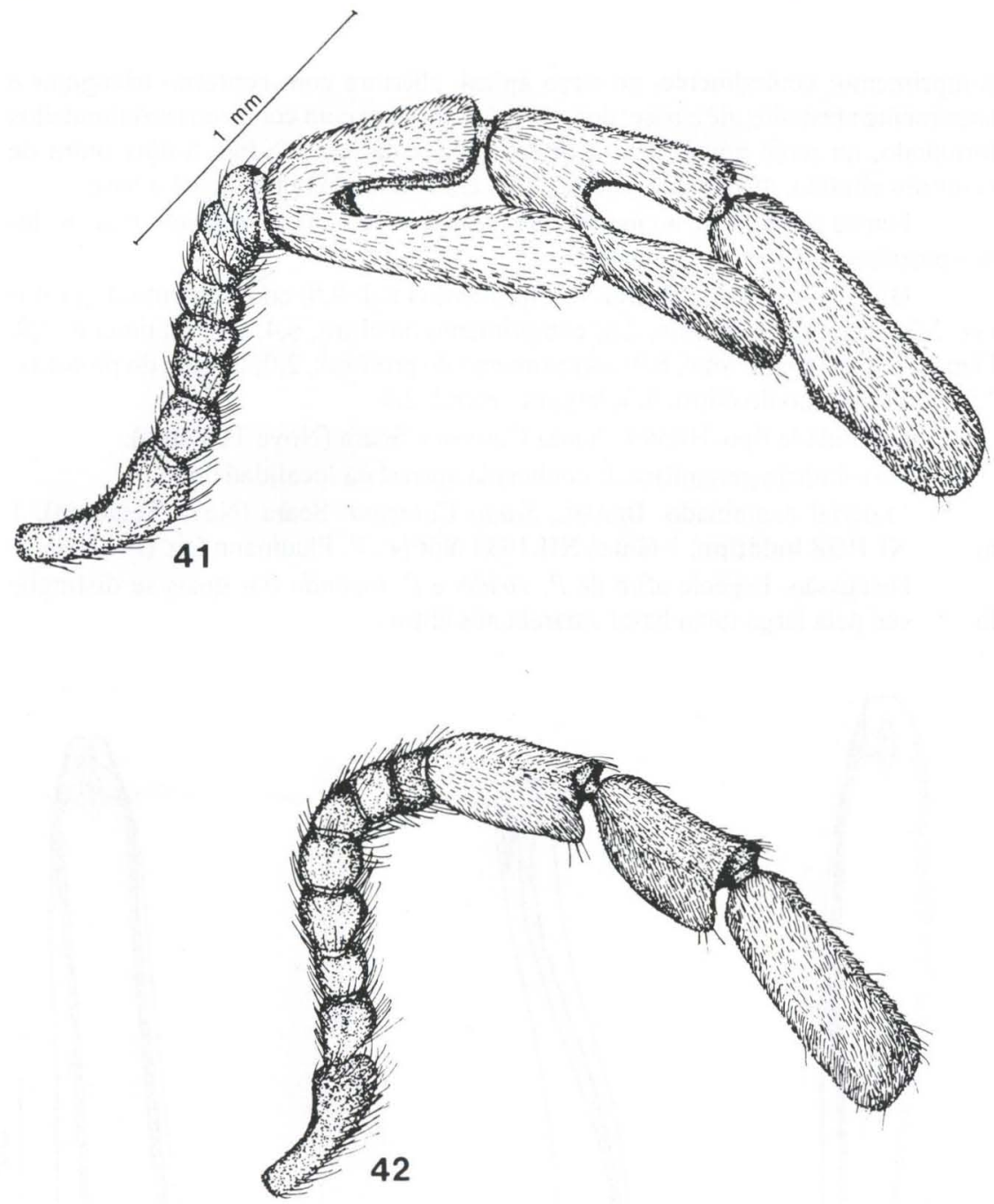

Figs 41-42. Philyra basalis (Racca Filho \& Santos, 1988), comb.n.. (41) Macho, antena; (42) fêmea, antena.

\section{Philyra helopioides Laporte, 1836}

Fig. 50

Philyra helopioides Laporte, 1836: 54. -Spinola, 1844: 377. - Lacordaire, 1857: 481. - Desmarest, 1876: 277.

Enoplium pulchellum Dejean, 1837: 128 (nomen nudum). - Spinola, 1844: 377. - Gemminger \& Harold, 1869: 1754.

Pelonium pulchellum: Spinola, 1844: 377, pr. 34, fig. 4. - Lacordaire, 1857: 481. - Gemminger \& Harold, 1869: 1754. - Schenkling, 1903: 106. - Schenkling, 1910: 130. 
Pelonium helopioides: Gemminger \& Harold, 1869: 1754. - Gorham, 1877: 418. - Schenkling, 1903: 106. -Schenkling, 1910: 130.

Pelonium semivittatum Chevrolat, 1876: 37. - Gorham, 1877: 418. - Schenkling, 1903: 106. -Schenkling, 1910: 130.

Corinthiscus helopioides: Blackwelder, 1945: 390. - Corporaal, 1950: 287.

Lasiodera helopioides: Peracchi, 1960: 67. - Ekis, 1975: 52.

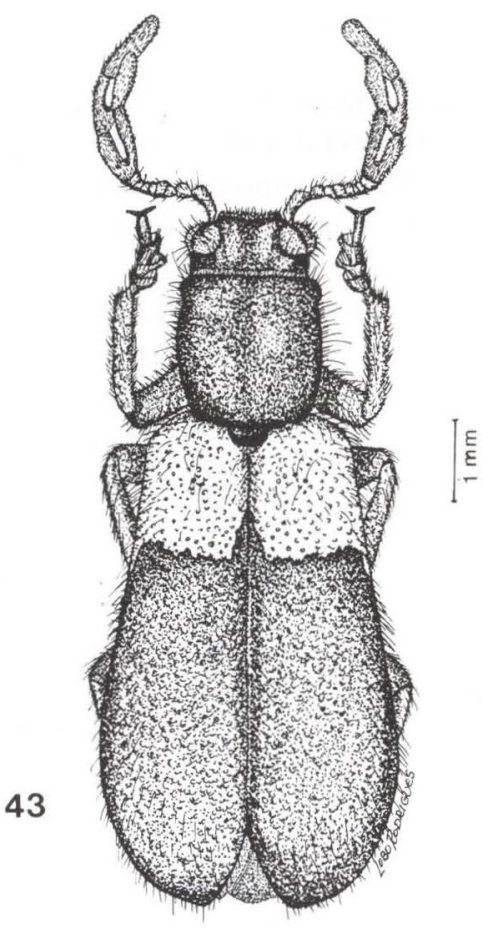

Fig. 43. Philyra basalis (Racca Filho \& Santos, 1988), comb.n., macho vista dorsal.

Redescrição. Fêmea (Fig. 50). Cabeça densamente pontuada, pilosa, verde brilhante; mandíbulas pretas com a base verde brilhante, com reflexos metálicos; labro castanho-amarelado; palpos maxilares e labiais amarelados; antenas amareladas, pilosas, com escapo robusto, alongado; os artículos do funículo diminuem gradativamente de comprimento da base para o ápice; clava antenal densamente pilosa, com pêlos curtos; os dois primeiros artículos com pequenas saliências apicais e o terceiro simples e alongado.

Protórax piloso, densamente pontuado, violáceo, com reflexos metálicos; fracamente convexo; bordo posterior um pouco mais estreito que o anterior; ângulos anteriores e posteriores ligeiramente arredondados. Escutelo subtriangular, verde brilhante, com pontos pilosos.

Élitros pilosos com pontos profundos arredondados, densamente distribuídos por toda a superfície, em conjunto arredondados no ápice, violáceos com 
reflexos verde metálicos, com duas faixas longitudinais, amarelas, sendo uma próximo à sutura e outra na margem, esta mais estreita e mais curta que aquela, unidas por uma faixa transversal, também amarela, situada no terço posterior, um tanto inclinada em direção à sutura e com margens sinuosas e de largura semelhante à daquela longitudinal próxima à sutura.

Pernas castanho-amareladas, com pontos pilosos; as anteriores com reflexos esverdeados nos ápices dos fêmures e nas metades basais das tíbias; unhas castanho-amareladas.

Tórax e abdome ventralmente de cor verde brilhante, com pontos pilosos; urosternitos com uma estreita faixa de cor castanha no ápice, sem pêlos.

Dimensões $(\mathrm{mm})$. Fêmea: Comprimento total, 7,6; comprimento do protórax, 1,5; largura do protórax, 1,6; comprimento do élitro, 5,6; largura umeral, 2,0.

Localidade tipo. BRASIL.

Distribuição geográfica. BRASIL: Espírito Santo.

Material examinado. BRASIL, Espírito Santo: Barra de São Francisco (Córrego do Itá), 1 fêmea XI.1956, W. Zikán leg. (IEEA).

Discussão. Espécie próxima de $P$. quadrivittata, diferenciando-se pela faixa transversal nos élitros unindo as faixas longitudinais dorsal e marginal, amarelas.
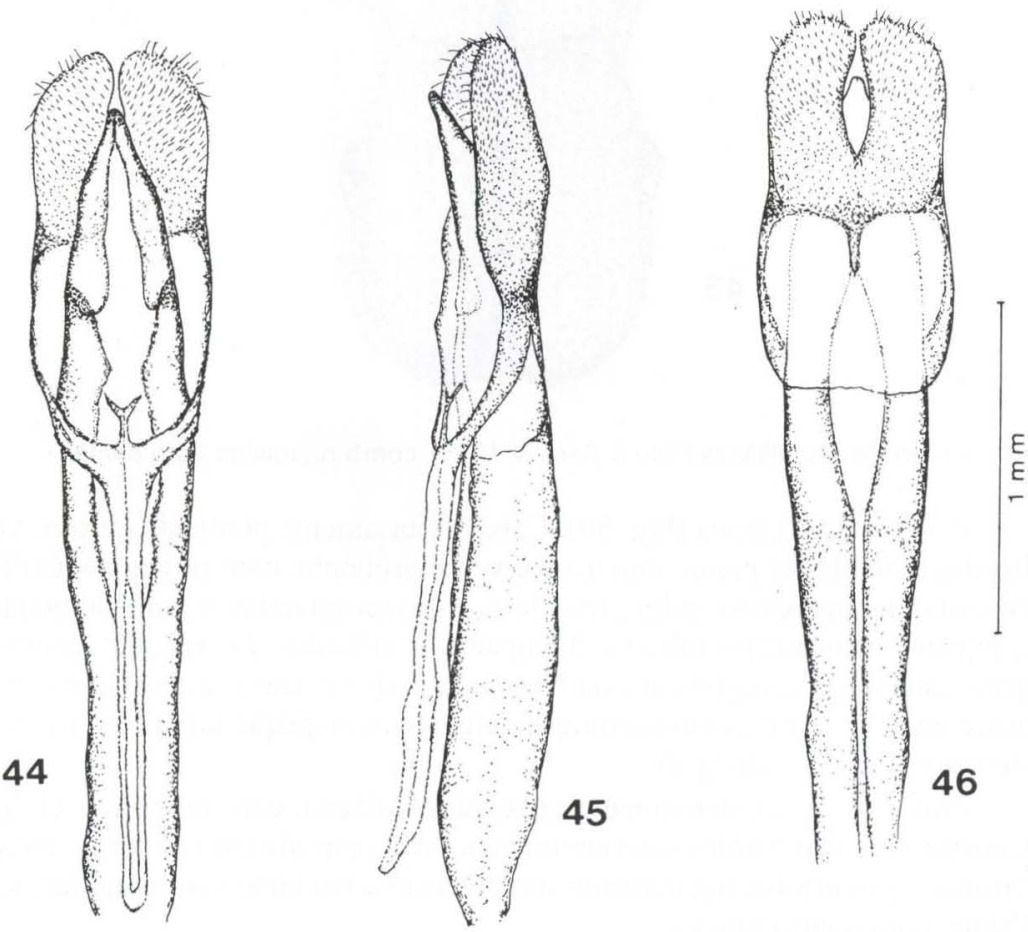

Figs 44-46. Philyra basalis (Racca Filho \& Santos, 1988), comb.n., edeago. (44) Vista ventral; (45) vista lateral; (46) vista dorsal. 

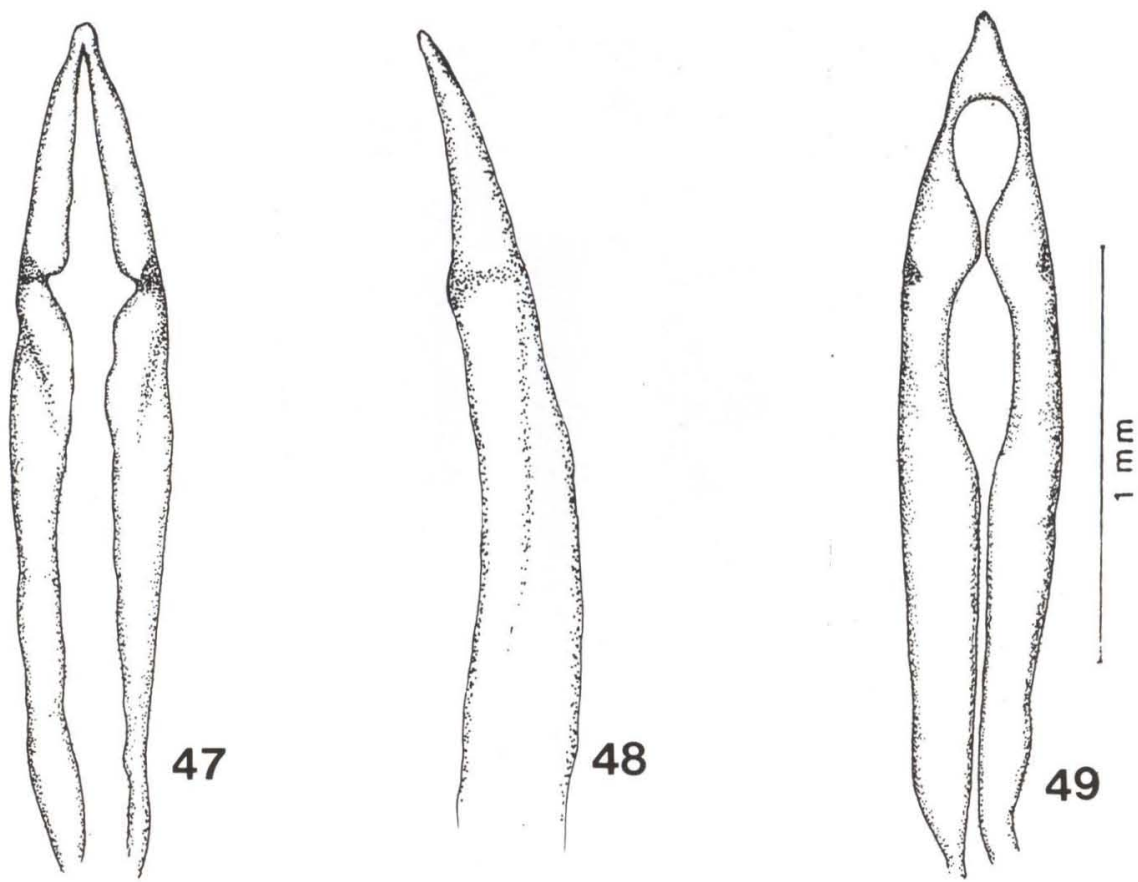

Figs 47-49. Philyra basalis (Racca Filho \& Santos, 1988), comb.n., lobo mediano do macho. (47) Vista ventral; (48) vista lateral; (49) vista dorsal.

\section{Philyra jucunda (Schenkling, 1900), comb.n. Figs $51-57$}

Pelonium jucundum Schenkling, 1900: 404. - Schenkling, 1903: 106, pl. 2, fig. 10. Schenkling, 1906: 312. Schenkling, 1910: 131.

Corinthiscus jucundus: Blackwelder, 1945: 390. - Corporaal, 1950: 288.

Lasiodera jucunda: Peracchi, 1962: 305. -Racca Filho \& Santos, 1988: 83.

Redescrição. Macho (Fig. 51). Cabeça orbicular, esverdeada com reflexos metálicos, densamente pontuada, com grande quantidade de pêlos esbranquiçados e pêlos castanhos esparsos; labro castanho ferrugíneo; olhos pretos com reflexos metálicos, com pêlos castanhos esparsos; mandíbulas pretas com reflexos esverdeados; palpos maxilares e labiais castanho ferrugíneos; antenas castanho ferrugíneas; pedicelo quase globoso; os artículos do funículo diminuem gradativamente de comprimento, da base para o ápice; clava mais longa que os demais artículos reunidos, com uma cobertura contínua de curtos e delicados pêlos castanhos, de aspecto sedoso e com pêlos pretos, curtos e fortes, ordenados em direção ao ápice, que sobressaem na cobertura subjacente; os dois primeiros artículos da clava providos na base de um ramo espatulado que se projeta para cima, ultrapassando o comprimento dos mesmos e, o terceiro simples, ovalado, alongado, com o ápice em sutil ponta, levemente encurvada. 


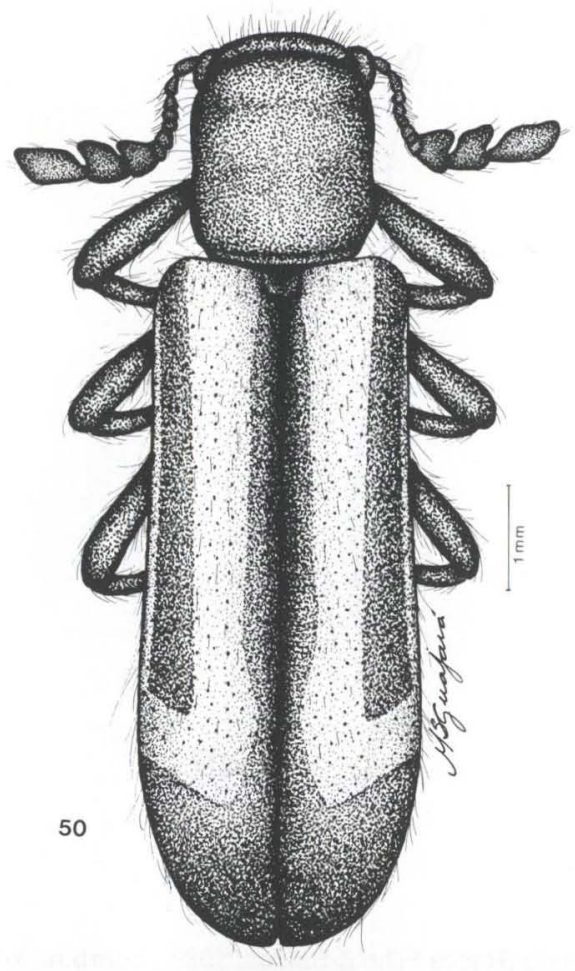

Fig. 50. Philyra helopioides Laporte, 1836, fêmea vista dorsal.

Protórax alongado, subcilíndrico, piloso, levemente convexo no dorso; pronoto densamente pontuado, com pontos grossos e profundos nos lados e com pontos menores e mais esparsos no dorso; com pilosidade castanha e esparsa, mais concentrada nos lados; verde escuro com reflexos violáceos; bordo anterior mais largo que o posterior; ângulos anteriores e posteriores arredondados; pro, meso e metasterno verde escuros com pilosidade esbranquiçada, concentrada no metasterno. Escutelo subcircular, verde escuro.

Pernas castanho ferrugineas, com pilosidade castanha e pêlos delicados esbranquiçados; coxas, ápice dos fêmures e margens externas das tíbias pretos com reflexos esverdeados; tarsos e unhas enegrecidos.

Élitros alongados, convexos, pilosos, com pilosidade castanha esparsa, com pontos profundos e muito densos, conferindo ao conjunto um aspecto reticulado, exceto nas manchas; verde escuros, com áreas violáceas, principalmente no meio da sutura; grande mancha amarela na base, formada por dois ramos: um próximo à sutura, em forma de cunha que percorre o terço basal, podendo aproximar-se da metade, e o outro em forma de estreita faixa que, após contornar os calos umerais, acompanha a margem por toda a metade basal, estreitando-se gradativamente; margens dilatando-se gradualmente a partir dos calos umerais, que são pouco proeminentes, até próximo ao ápice, onde abruptamente se projetam em arco de círculo. 


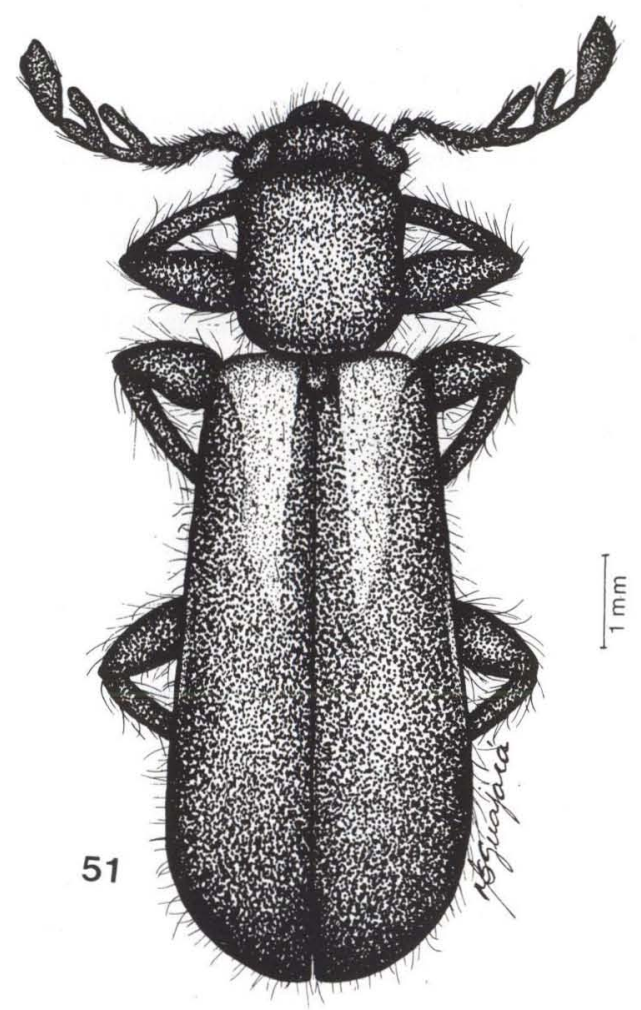

Fig. 51. Philyra jucunda (Schenkling, 1900), comb.n., macho vista dorsal.

Abdome verde escuro, com reflexos metálicos, com pilosidade esbranquiçada, principalmente nas margens posteriores dos urosternitos.

Dois exemplares apresentam pronoto e élitros violáceos com reflexos verde escuros.

Genitália (Figs 52-57). Peça basal ultrapassando o ponto de união com os lobos laterais numa projeção acuminada simples, quase tão longa quanto o terço basal dos mesmos. Lobos laterais com um espessamento transversal, um pouco acima do meio. Lobo mediano de ápice abruptamente acuminado e base fendida; abertura ventral de contornos irregulares, sendo que no terço apical quase atingindo o ápice; ventralmente as aberturas têm contornos subelípticos, também no terço apical; em vista lateral o terço apical levemente encurvado, com uma projeção acuminada decorrente da parede da abertura ventral.

Fêmea semelhante ao macho.

Dimensões (mm). Macho (4 exemplares): Comprimento total, 6,2-8,4; comprimento do protórax, 1,3-1,8; largura do protórax, 1,2-1,7; comprimento do élitro, 4,4-6,0; largura umeral, 1,6-2,2. Fêmea (2 exemplares): comprimento total, 8,3-8,6; comprimento do protórax, 1,8-2,2; largura do protórax, 1,6-1,8; comprimento do élitro, 6,1-6,2; largura umeral, 2,1-2,3. 
Localidade tipo. BRAsIL, Goiás.

Distribuição geográfica. BRASIL: Goiás, Santa Catarina.

Material examinado. BrasiL, Santa Catarina: Seara (Nova Teutônia), 1 macho 20.XI.1950, 1 fêmea 01.XI.1951, 1 macho 01.XII.1951, 1 macho 02.XII. 1951, 1 macho 05.XII.1951, 1 fêmea I.1963, F. Plaumann leg. (FMNH).

Discussão. Espécie próxima de $P$. stenochioides da qual se distingue facilmente por não apresentar a faixa transversal amarela no terço posterior do élitro.
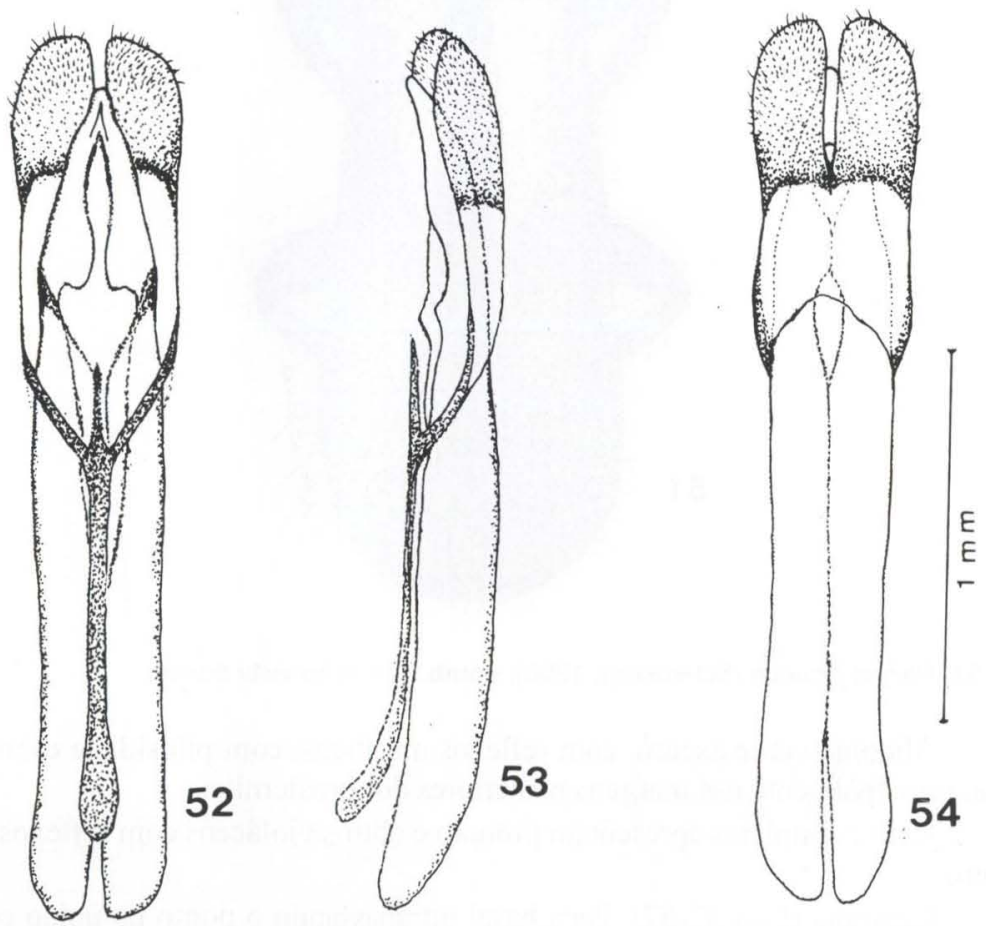

Figs 52-54. Philyra jucunda (Schenkling, 1900), comb.n., edeago. (52) Vista ventral; (53) vista lateral; (54) vista dorsal.

\section{Philyra quadrivittata (Peracchi, 1960), comb.n. Figs 58-64}

Lasiodera quadrivittata Peracchi, 1960: 139.

Redescrição do Holótipo. Macho (Fig. 58). Cabeça pilosa, verde metálico claro; fronte com pontos pequenos, densamente distribuídos; vértice com pontuação mais profunda e esparsa; olhos pretos pouco salientes; clípeo e labro amarelos; mandíbulas pretas na metade apical e verde metálico na base; palpos maxilares e labiais amarelos; antenas pilosas com os oito primeiros artículos castanho-amarelados; escapo robusto, alongado e encurvado; os artículos do funículo diminuem 
gradativamente de comprimento da base para o ápice; clava antenal mais longa que os demais artículos reunidos, amarelo vivo, com os dois primeiros artículos providos na base de um ramo que excede os respectivos comprimentos, terceiro artículo simples, ovalado e alongado.
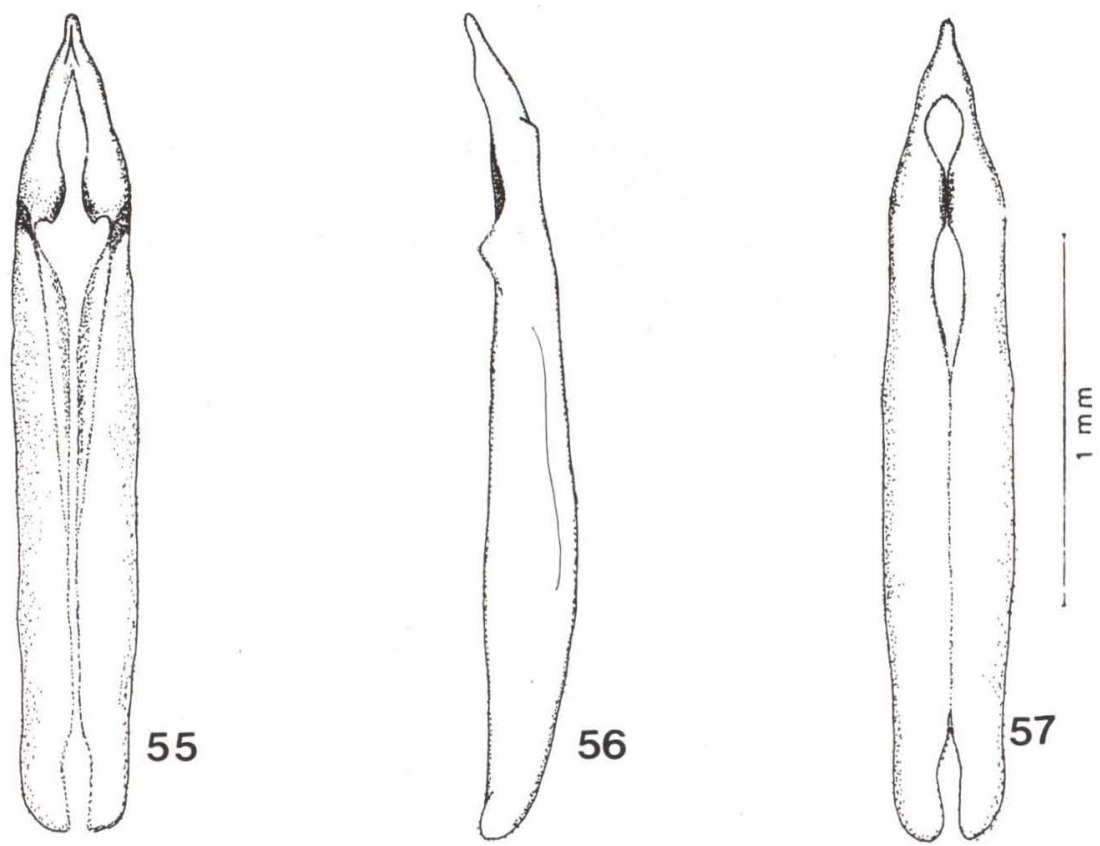

Figs 55-57. Philyra jucunda (Schenkling, 1900), comb.n., lobo mediano do macho. (55) Vista ventral; (56) vista lateral; (57) vista dorsal.

Protórax piloso, lateralmente violáceo metálico com pontos grossos e profundos, densamente distribuídos; dorsalmente de colorido metálico variável com a incidência de luz, mas predominantemente verde, com pontos esparsos; ventralmente verde metálico claro; tão longo quanto largo, uniforme e fracamente convexo; ângulos anteriores e posteriores ligeiramente arredondados; bordo posterior tão largo quanto o anterior; escutelo reniforme, verde metálico, com pontos pilosos.

Pernas com pontos pilosos; coxas e fêmures (exceto a base castanho-amarelada) de colorido verde metálico; tíbias verde azulado; tarsos castanho-amarelados; unhas pretas.

Mesotórax e metatórax, lateral e ventralmente, verde metálico claro.

Élitros alongados, convexos, mais largos que o protórax na base; menos pilosos que a cabeça e o protórax; em conjunto arredondados no ápice, com pontos profundos densamente distribuídos, tão contíguos dando ao conjunto aspecto reticulado; violáceos foscos, na sutura com tendência para o azul; cada élitro com duas faixas amareladas, estreitamente ligadas na região umeral, parecendo indepen-dentes; a mais externa marginal com até $2 / 3$ do comprimento do élitro, a segunda, 
próxima da sutura, comprimindo-se progressivamente até pouco além do meio, formando uma constrição, a seguir dilata-se e termina pouco além da primeira faixa descrita.

Abdome piloso, verde azulado, exceto uma faixa transversal distal, dourada, em cada urosternito.

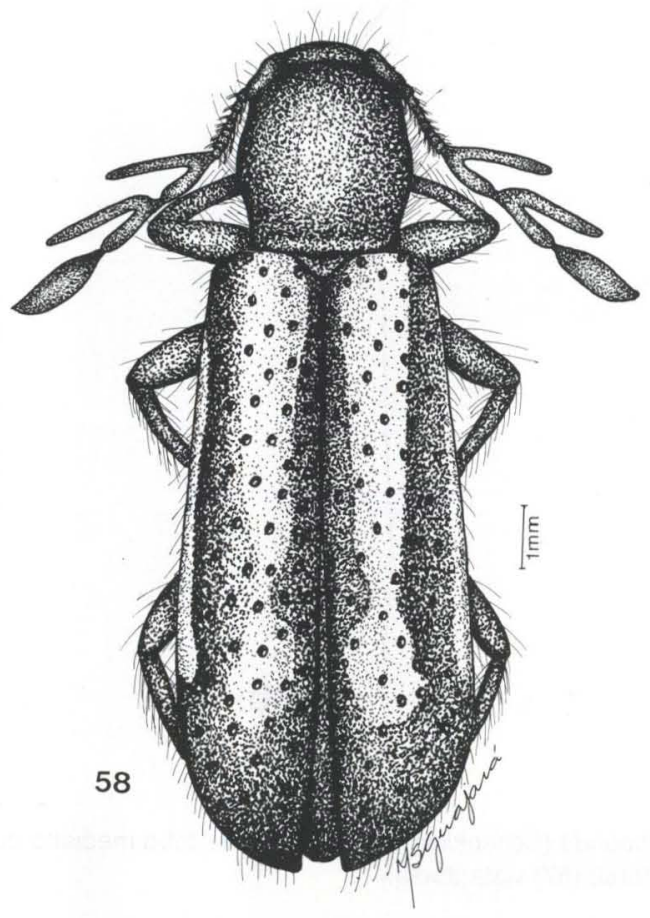

Fig. 58. Philyra quadrivittata (Peracchi, 1960), comb.n., macho vista dorsal.

Genitália (Figs 59-64). Peça basal ultrapassando o ponto de união com os lobos laterais em uma projeção curta, acuminada, triangular; terço basal mais arqueado que em $P$. basalis e $P$. jucunda. Lobos laterais unidos dorsalmente na metade basal e afastados na metade apical, com uma abertura mais estreita que em $P$. basalis e $P$. jucunda. Lobo mediano, ventralmente, aberto em quase toda sua extensão; no ápice abertura de forma triangular, com um estrangulamento logo abaixo, onde as paredes laterais se dobram para dentro e, a partir deste ponto os bordos afastam-se progressivamente em direção à base; dorsalmente com uma abertura sub-oval no terço apical e outra, menor, subelíptica próxima ao meio; a partir desta com uma sutura em direção à base; lateralmente com uma projeção acuminada no terço apical, decorrente das dobras das paredes ventrais.

Fêmea semelhante ao macho, exceto pelo protórax ligeiramente mais longo que largo, pela faixa mais interna do élitro que não sofre constrição visível, com sua 
extremidade distal ligeiramente dilatada para fora e pela coloração das pernas: fêmures castanhos com reflexos verde metálicos e tíbias de um violáceo claro.

Dimensões (mm). Macho: Comprimento total, 11,5; comprimento do protórax, 2,5; largura do protórax, 2,5; comprimento do élitro, 8,0; largura umeral, 4,0. Fêmea: comprimento total, 13,5; comprimento do protórax, 3,0; largura do protórax, 2,5; comprimento do élitro, 9,0; largura umeral, 4,0.
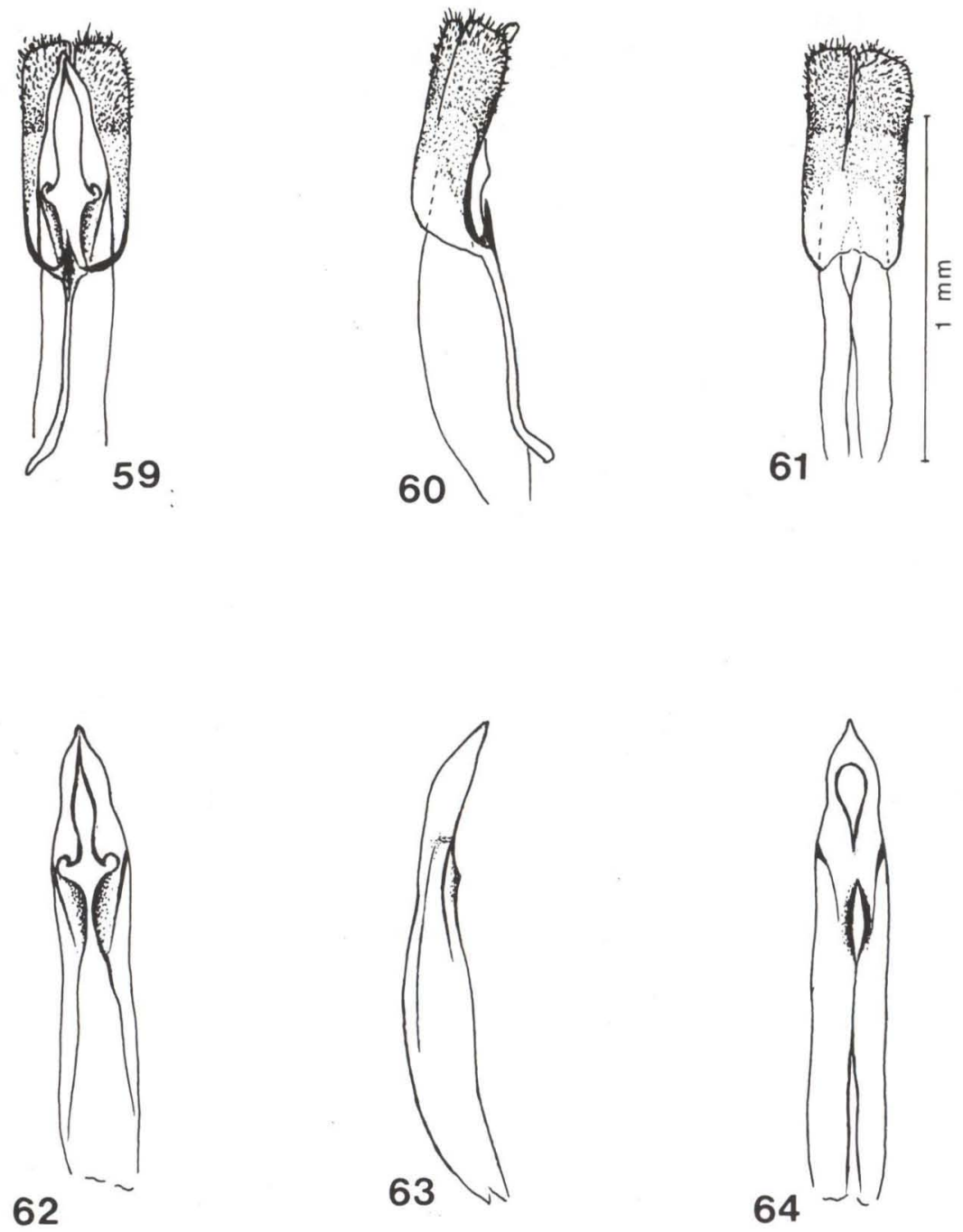

Figs 59-64. Philyra quadrivittata (Peracchi, 1960), comb.n., macho. (59-61) Edeago, (59) vista ventral, (60) vista lateral, (61) vista dorsal. (62-64) Lobo mediano, (62) vista ventral, (63) vista lateral; (64) vista dorsal. 

do Itá).

Localidade tipo. BRASIL, Espirito Santo: Barra de São Francisco (Córrego tipo.

Distribuição Geográfica. Até o momento conhecida apenas da localidade

Material examinado. BRASIL, Espirito Santo: Barra de São Francisco (Córrego do Itá), 1 macho XI.1956 holótipo, W. Zikán leg. (CACS); 1 fêmea, XI.1954 alótipo, W. Grossmann leg. (CACS); 1 fềmea 01-09.II.1957 parátipo, J.H. Guimarães leg. (CACS).

Discussão. Esta espécie é afim de $P$. helopioides, mas distingue-se facilmente por não apresentar as duas faixas de cada élitro largamente unidas um pouco além do meio.

\section{Philyra stenochioides (Chevrolat, 1874) comb.n.} Figs 65-71

Pelonium stenochioides Chevrolat, 1874: 325. - Schenkling, 1903: 106.

Lasiodera stenochioides: Schenkling, 1910: 127. - Blackwelder, 1945: 390. - Corporaal, 1950: 278.

Redescrição. Macho (Fig. 65). Cabeça verde brilhante com reflexos metálicos, pontuada, pilosa, com pêlos castanhos; labro amarelado; mandíbulas pretas; palpos maxilares e labiais amarelados; antenas castanho-amareladas com pêlos pretos; seis artículos do funículo subiguais, de forma quase anelar; os três artículos seguintes formam a clava, com os dois primeiros expandidos lateralmente na região basal, sendo as expansões mais longas que o próprio artículo e o terceiro oval terminando em ponta levemente pronunciada.

Protórax violáceo, brilhante, densamente pontuado; ângulos anteriores e posteriores arredondados; fracamente convexo; bordo posterior um pouco mais estreito que o anterior; bordos laterais com ligeira constrição na parte anterior. Escutelo subtriangular, verde brilhante com pontos pilosos.

Pernas castanho-amareladas com o ápice dos fềmures com reflexos esverdeados brilhantes, assim como as partes externas das tíbias, variando com a incidência da luz; tarsos castanhos e unhas castanho-amareladas.

Élitros pilosos, violáceos, brilhantes, com reflexos verdes, principalmente na sutura; com pontos profundos densamente distribuídos por toda a superfície; com uma mancha basal cuneiforme amarela, que se estende da base e estreitando-se para o ápice até próximo à sua metade; essa faixa estreitamente unida, na região umeral, à uma faixa, também amarela, que se estende marginalmente até um pouco além da metade do élitro, onde se une à uma faixa transversal, igualmente amarela, que se estende até próximo à sutura e que apresenta os bordos sinuosos.

Tórax e abdome ventralmente de cor verde brilhante, pilosos.

Genitália (Figs 66-71). Peça basal ultrapassando o ponto de união com os lobos laterais, com uma projeção delgada e acuminada. Lobos laterais, em vista lateral, com uma incisão que parte da base em direção ao ápice, de forma sinuada acompanhando o contorno do bordo ventral, até um pouco acima da metade; em vista dorsal, unidos até próximo ao terço apical, onde estão separados de forma mais 
acentuada que em $P$. viridis. Lobo mediano, ventralmente, com uma incisão, apical, em forma de "V" invertido; a partir desta incisão, abertos até próximo à metade, formando desenho de contorno característico; dorsalmente com uma abertura subelíptica no terço apical e a partir desta com uma incisão longitudinal em direção à base.

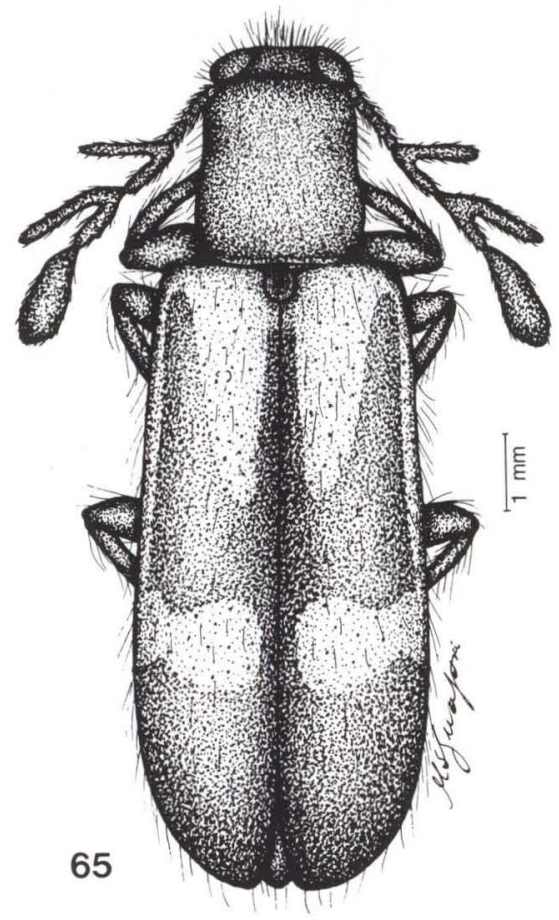

Fig. 65. Philyra stenochioides (Chevrolat, 1874), comb.n., macho vista dorsal.

Fêmea semelhante ao macho.

Dimensões (mm). Macho (30 exemplares): Comprimento total, 6,6-10,6; comprimento do protórax, 1,4-2,2; largura do protórax, 1,5-2,3; comprimento do élitro, 5,0-7,7; largura umeral, 1,8-3,0. Fêmea (45 exemplares): comprimento total, 7,0-11,2; comprimento do protórax, 1,6-2,5; largura do protórax, 1,4-2,4; comprimento do élitro, 5,1-8,0; largura umeral, 1,9-3,3.

Localidade tipo. MÉXICO.

Distribuição geográfica. MÉXICO (Chevrolat 1874); Brasil: Mato Grosso do Sul, São Paulo, Paraná, Santa Catarina.

Material examinado. BRASIL, Mato Grosso do Sul: Bataguaçu (Rio Caraguata), 1 macho X.1952, F. Plaumann leg. (?); São Paulo: São Paulo (Jabaquara), 1 fêmea 17.XI.1938, Zellibor e Hauff leg. (HZ); Paraná: Arapongas, 1 fêmea XII.1951, A. Maller leg. (CACS), Foz do Iguassu, 1 macho VII.1941, sem coletor, 

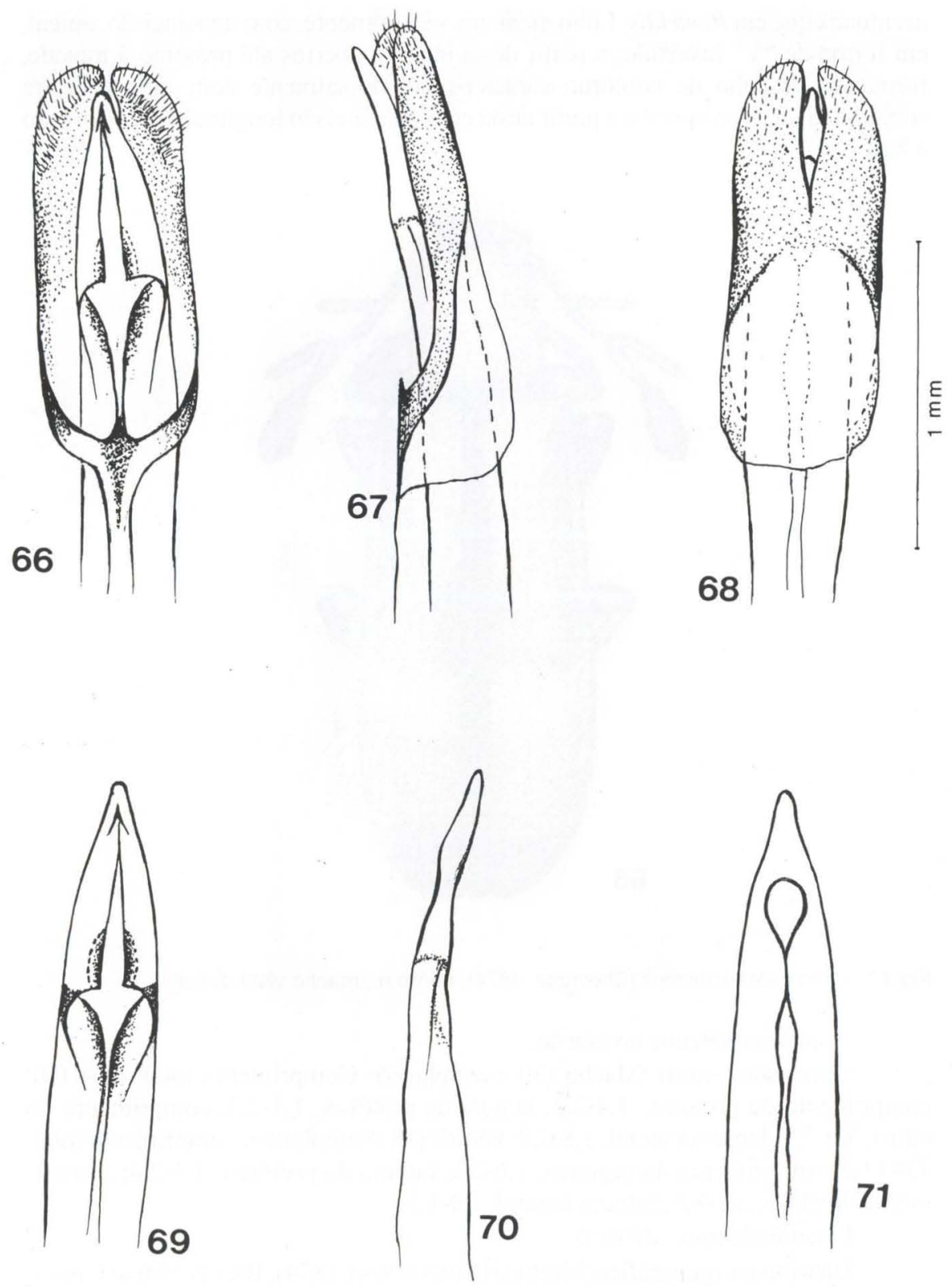

Figs 66-71. Philyra stenochioides (Chevrolat, 1874), comb.n., macho. (66-68) Edeago, (66) vista ventral, (67) vista lateral, (68) vista dorsal. (69-71) Lobo mediano, (69) vista ventral, (70) vista lateral, (71) vista dorsal. 
(ALP); Rondon, 1 macho 29.VIII.1952, 1 fêmea 31.VIII.1952, 2 machos 06.IX. 1952, 2 machos e 4 fêmeas 07.IX.1952, 3 fêmeas 08.IX.1952, 1 fềmea 10.IX.1952, 5 fềmeas 12.IX.1952, 3 machos e 1 fềmea 13.IX.1952, 1 fêmea 14.IX.1952, 2 machos e 6 fềmeas 16.IX.1952, 1 macho e 1 fềmea 17.IX.1952, 1 fềmea 05.IX.1952, 1 macho e 1 fềmea 20.IX.1952, 1 macho e 2 fềmeas 23.IX.1952, 1 macho 25.IX. 1952, 3 machos 26.IX.1952, 2 machos e 3 fêmeas 30.IX.1952, 1 fêmea 01.X.1952, 1 macho 04.X.1952, 1 macho 03.X.1952, 1 macho e 4 fêmeas 06.X.1952, 1 fềmea 09.X.1952, 1 macho e 1 fêmea 10.X.1952, 2 fêmeas 11.X.1952, 1 fêmea 12.X.1952, 1 macho 13.X.1952, 1 fềmea 14.X.1952, 1 macho e 1 fêmea 18.X.1952, 1 macho 25.X.1952, 1 macho 27.X.1952, 1 macho 20.XI.1952, F. Plaumann leg. (FMNH); Santa Catarina: Seara (Nova Teutônia), 1 fêmea 04.XI.1951, F. Plaumann leg. (FMNH).

Discussão. Espécie muito próxima de $P$. jucunda, mas com uma faixa transversal um pouco além da metade dos élitros.

\section{Philyra viridis (Pic, 1936), comb.n.}

Figs $72-78$

Pelonium viride Pic, 1936: 20.

Corinthiscus viridis: Blackwelder, 1945: 391;. - Corporaal, 1950: 287.

Lasiodera viridis: Peracchi, 1960: 67.

Redescrição. Macho (Fig. 72). Cabeça pontuada, pilosa, verde brilhante, com reflexos metálicos; olhos pretos com reflexos violáceos; labro e palpos maxilares e labiais castanho-amarelados; mandíbulas pretas; antenas pilosas, pretas, com reflexos verde metálicos nos oito primeiros artículos; os artículos do funículo diminuem gradativamente de comprimento da base para o ápice; clava antenal com pilosidade abundante, com pêlos mais curtos que aqueles dos demais artículos, com os dois primeiros artículos tendo na base um ramo que excede os respectivos comprimentos e o terceiro, oval, simples e alongado.

Protórax piloso, verde brilhante com reflexos metálicos; com pontos grossos e profundos densamente distribuídos nos lados e pontos menores e mais esparsos no dorso; fracamente convexo; ângulos anteriores e posteriores ligeiramente arredondados; ligeiramente estrangulado na base, então com o bordo anterior pouco mais largo que o posterior. Escutelo subtriangular, verde metálico com pontos pilosos.

Pernas pilosas, verde metálicas, com reflexos violáceos; tarsos pretos; unhas castanhas.

Élitros pilosos, com pontos densamente distribuídos, de coloração verde metálica uniforme; alongados, convexos, envolvendo lateralmente o abdome.

Abdome piloso, verde metálico, exceto uma faixa apical castanha, em cada urosternito.

Genitália (Figs 73-78). Peça basal não ultrapassando o ponto de união com os lobos laterais. Lobos laterais unidos dorsalmente na metade basal, com um espessamento sinuado e um tanto inclinado, um pouco acima da metade basal, visível em todas as vistas; em vista lateral com perfil estreito. Lobo mediano, em 
vista ventral, com uma incisão em forma de "Y" invertido próxima ao ápice; aberto até a base a partir de um ponto logo abaixo da citada incisão, com um contorno de forma aproximada à de um losango; dorsalmente, com uma abertura subelíptica no terço apical e outra com a mesma forma, mais estreita, próxima à metade; a partir desta abertura com uma incisão longitudinal até a base.

Fêmea semelhante ao macho.

Dimensões (mm). Macho (2 exemplares): Comprimento total, 7,3-8,0; comprimento do protórax, 1,6-1,8; largura do protórax, 1,6-1,7; comprimento do élitro, 5,1-5,6; largura umeral, 2,0-2,1. Fêmea: comprimento total, 9,4; comprimento do protórax, 2,0; largura do protórax, 2,1; comprimento do élitro, 6,4; largura umeral, 2,5 .

Localidade tipo. BrasiL, Santa Catarina: Seara (Nova Teutônia).

Distribuição Geográfica. Até o momento conhecida apenas da localidade tipo.

Material examinado. Brasil, Santa Catarina: Seara (Nova Teutônia), 1 macho 05.IV.1945, F. Plaumann leg. (FMNH), 1 macho e 1 fềmea sem data, F. Plaumann leg. (IEEA).

Discussão. Esta espécie é facilmente diferenciada das demais por apresentar coloração verde metálica uniforme.

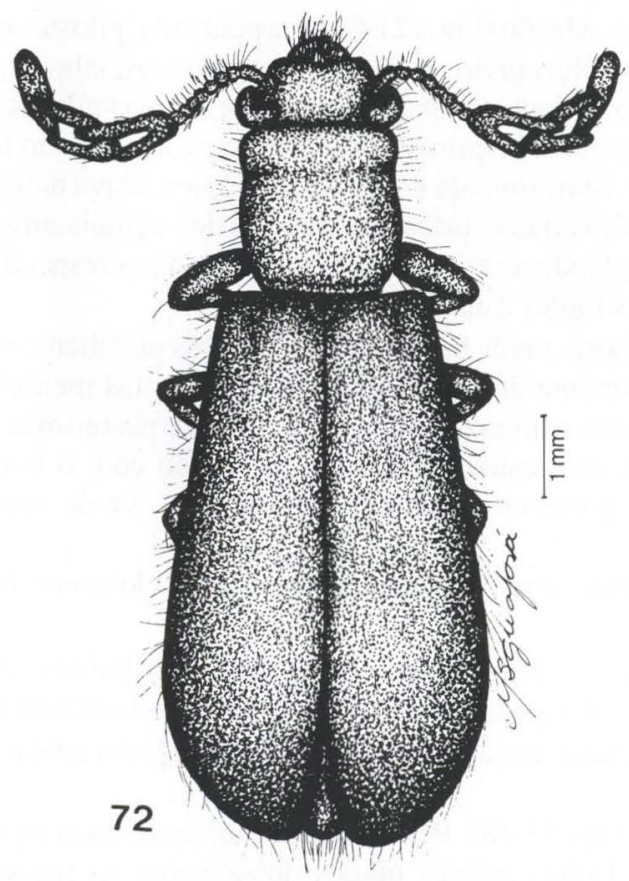

Fig. 72. Philyra viridis (Pic, 1936), comb.n., macho vista dorsal. 

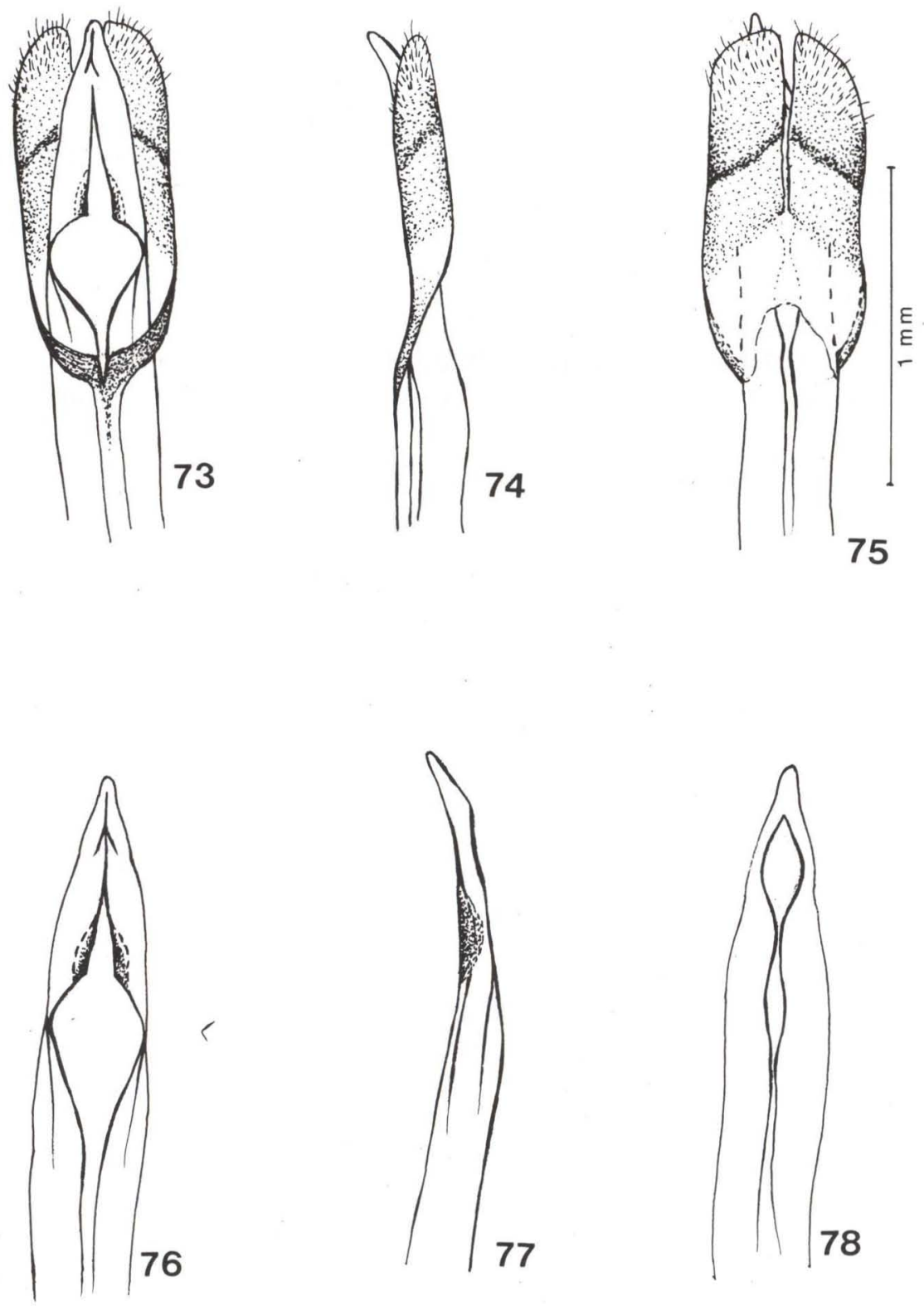

Figs 73-78. Philyra viridis (Pic, 1936), comb.n., macho. (73-75) Edeago, (73) vista ventral, (74) vista lateral, (75) vista dorsal. (76-78) Lobo mediano, (76) vista ventral, (77) vista lateral, (78) vista dorsal.

AGRADECIMENTOS. Os autores agradecem aos professores Mariângela da Silva Guajará e Irineu Lobo Rodrigues Filho (Universidade Federal Rural do Rio de Janeiro), pela confecção dos desenhos. 


\section{REFERÊNCIAS BIBLIOGRÁFICAS}

BLACK WELDER, R.E. 1945. Checklist of the coleopterous insects of Mexico, Central America, the West Indies, and South America. Bull. U.S. Nat. Mus. 185 (3): 343-550.

BRUCH, C. 1915. Catálogo sistemático de los coleópteros de la República Argentina VI. Rev. Mus. La Plata 19: 235-339.

Chevrolat, L.A.A. 1874. Catalogue des clerides de la collection de M.A. Chevrolat. Rev. \& Mag. Zool. (3) 2: 252-329.

1876. Mémoire sur la famille des clérites. Paris, $51 \mathrm{p}$.

CorporaAl, J.B. 1948. Nineteen notes on systematics and synonymy. Ent. Ber., Amsterdam, 12: 242-246.

Ed., 373p.

Costa Lima, A.M. 1921. Técnica para a preparação e montagem de pequenos insetos para o exame microscópico. Arch. Esc. Sup. Agric. Med. Vet., Rio de Janeiro, 5: 123-126.

1953. Insetos do Brasil: Coleópteros. Rio de Janeiro, Escola Nacional de Agronomia, vol. 8, $2^{\mathrm{a}}$ parte, 324p.

DeJEAN, P.F.M.A. 1837. Catalogue des coléoptères de la collection de M. le Comte Dejean. Paris, Troisième édition, livr. 1-4, p.1-384.

Desmarest, E. 1876. Coléoptères, p.226-279. In: J.C. Chenu (Ed.) Encyclopédie d'histoire naturelle. Paris, Firmin-Didot, Tome 2.

EKIS, G. 1975. Taxonomic and nomenclatural status of clerid taxa described by Massimiliano Spinola (1780-1857) (Coleoptera, Cleridae). Boll. Mus. Zool. Univ. Tor. 1: 1-80.

Fairmaire, L. \& P. Germain. 1861. Coleoptera chilensia. Paris, Part. 2, section $2,8 \mathrm{p}$.

GAHAN, C.J. 1910. Notes on Cleridae and Descriptions of some new Genera and Species of this Family of Coleoptera. Ann. \& Mag. Nat. Hist. 5 (8): 55-76.

GEMminger, M. \& E. vON HAROLD. 1869. Catalogus coleopterorum hucusque descriptorum synonymicus et systematicus. Monachii, 6: 1609-1800.

GoRHAM, H.S. 1877. Description of new species of Cleridae, with notes on the genera and corrections of synonymy. Trans. ent. Soc. London 4: 401-426.

GRAY, E. 1832. Notices of new genera and species. In: GRIFFITH \& PIDGEON (Ed.). The animal kingdom arranged in conformity with its organization by the Baron Cuvier. London, vol. 14, 570p.

JeAnNel, R. \& R. Paulian. 1944. Morphologie abdominale des coléoptères et systematique de l'ordre. Rev. Franc. d'Ent. 11: 66-110.

KLUG, J.C.F. 1842. Versuch einer systematischen Bestimmung und Auseinandersetzung der Gattungen und Arten der Clerii, einer Insektenfamilie aus der Ordnung der Coleopteren. Abh. Preussische Akad. Wiss., Berlin, p.259-397.

LACORDAIRE, J.T. 1857-1876. Histoire naturelle des insectes. Genera des coléoptères ou exposé méthodique e critique de tous les genres proposés jusqu'ici 
dans cet ordre d'insectes. Paris, Librairie Encyclopédique de Roret, vol. 4, $579 \mathrm{p}$.

LAPORTE, F.L.N. DE (comte de Castelnau). 1836. Études entomologiques, ou descriptions d'insectes nouveaux et observations sur la synonymie. Revue Ent., Paris, 4: 5-60.

LATREILlE, P.A. 1802. Histoire naturelle, génerále et particulière, des crustacés et des insectes. Paris, vol.3, 467p.

LECONTE, J.L. 1861. Classification of Coleoptera of North America. Prepared for the Smithsonian Institution. Smiths. Misc. Coll. 136: 1-208.

LUCAS, P.H. 1857. Entomologie. Animaux nouveaux ou rares recueillis pendant l'expédition dans les parties centrales de l'Amérique du Sud, Rio de Janeiro a Lima, et de Lima au Para; exécutée par ordre du Gouvernement français pendant les années 1843 a 1847 , sous la direction du Comte de Castelnau. Paris, 204p.

PERACCHI, A.L. 1960a. Contribuição ao estudo dos cléridas neotropicais (Coleoptera, Cleridae). Rev. Bras. Biol. 20 (1): 63-68.

- 1960b. Nova espécie de clérida do Brasil (Coleoptera, Cleridae). Rev. Bras. Biol. 20 (2): 139-142.

1962. Contribuição ao estudo dos cléridas do Brasil (Coleoptera, Cleridae). Rev. Bras. Biol. 22 (3): 299-306.

PIC, M. 1933. Nouveaux coléoptères américains. Bull. Soc. ent. France 38 (18): 292-294. 51: 20 .

RACCA Filho, F. \& C.A.C. Dos SAnTos. 1988. Contribuição ao estudo do gênero Lasiodera Gray, 1832 (Coleoptera, Cleridae): I. Redescrição de Lasiodera jucunda (Schenkling, 1900) e descrição de uma nova espécie. Arq. Univ. Fed. Rur. Rio de Janeiro, Itaguaí, 11 (1-2): 83-92.

SCHENKLING, S. 1900. Neue amerikanische Cleriden nebst Bemerkungen zu schon beschriebenen Arten. Deutsche ent. Zeitschr. (2): 385-409.

1903. Fam. Cleridae. In: P. WYTMAN (Ed.). Genera insectorum. 13. Coleoptera, Malacodermata. Bruxelles, 124p.

1906. Die Cleriden des Deutschen Entomologischen National-Museums, nebst Beschreibungen neuer Arten. Deutsche ent. Zeitschr. (1): 241-320.

1910. Coleopterorum catalogus. 23. Cleridae. Berlin, W. Junk Ed., $174 \mathrm{p}$.

SHARP, D. \& F. MUIR. 1912. The comparative anatomy of the male genital tube in Coleoptera. Trans. ent. Soc. London 3: 477-642.

SPINOLA, M. 1844. Essai Monographique sur les Clérites, Insectes Coléoptères, Gênes. I: IX+386p.; II: 119p.; Suppl.: p.121-216.

THOMSON, J. 1860. Matériaux pour servir a une monographie nouvelle de la famille des clérides. Mus. Scient., Paris, 1: 46-67.

Recebido em 01.XII.1992; aceito em 05.IX.1996. 